\title{
Trends in peroxyacetyl nitrate (PAN) in the upper troposphere and lower stratosphere over southern Asia during the summer monsoon season: regional impacts
}

\author{
S. Fadnavis ${ }^{1}$, M. G. Schultz ${ }^{2}$, K. Semeniuk ${ }^{3}$, A. S. Mahajan ${ }^{1}$, L. Pozzoli ${ }^{4}$, S. Sonbawne ${ }^{1}$, S. D. Ghude ${ }^{1}$, M. Kiefer ${ }^{5}$, and \\ E. Eckert ${ }^{5}$ \\ ${ }^{1}$ Indian Institute of Tropical Meteorology, Pune, India \\ ${ }^{2}$ Institute of Energy and Climate Research - Troposphere (IEK-8), Forschungszentrum Jülich, Jülich, Germany \\ ${ }^{3}$ Department of Earth and Space Sciences and Engineering, York University, Toronto, Canada \\ ${ }^{4}$ Eurasia Institute of Earth Sciences, Istanbul Technical University, Istanbul, Turkey \\ ${ }^{5}$ Karlsruhe Institute of Technology, Institute for Meteorology and Climate Research, Karlsruhe, Germany
}

Correspondence to: S. Fadnavis (suvarna@tropmet.res.in)

Received: 18 June 2014 - Published in Atmos. Chem. Phys. Discuss.: 22 July 2014

Revised: 9 October 2014 - Accepted: 28 October 2014 - Published: 4 December 2014

\begin{abstract}
We analyze temporal trends of peroxyacetyl nitrate (PAN) retrievals from the Michelson Interferometer for Passive Atmospheric Sounding (MIPAS) during 20022011 in the altitude range $8-23 \mathrm{~km}$ over the Asian summer monsoon (ASM) region. The greatest enhancements of PAN mixing ratios in the upper troposphere and lower stratosphere (UTLS) are seen during the summer monsoon season from June to September. During the monsoon season, the mole fractions of PAN show statistically significant (at $2 \sigma$ ) positive trends from $0.2 \pm 0.05$ to $4.6 \pm 3.1 \mathrm{ppt} \mathrm{yr}^{-1}$ (except between 12 and $14 \mathrm{~km}$ ) which is higher than the annual mean trends of $0.1 \pm 0.05$ to $2.7 \pm 0.8 \mathrm{ppt} \mathrm{yr}^{-1}$. These rising concentrations point to increasing $\mathrm{NO}_{\mathrm{x}}(=\mathrm{NO}+\mathrm{NO} 2)$ and volatile organic compound (VOC) emissions from developing nations in Asia, notably India and China.

We analyze the influence of monsoon convection on the distribution of PAN in UTLS with simulations using the global chemistry-climate model ECHAM5-HAMMOZ. During the monsoon, transport into the UTLS over the Asian region primarily occurs from two convective zones, one the South China Sea and the other over the southern flank of the Himalayas.

India and China host $\mathrm{NO}_{\mathrm{x}}$-limited regimes for ozone photochemical production, and thus we use the model to evaluate the contributions from enhanced $\mathrm{NO}_{\mathrm{x}}$ emissions to the changes in $\mathrm{PAN}, \mathrm{HNO}_{3}$ and $\mathrm{O}_{3}$ concentrations in the
\end{abstract}

UTLS. From a set of sensitivity experiments with emission changes in particular regions, it can be concluded that Chinese emissions have a greater impact on the concentrations of these species than Indian emissions. According to SCanning Imaging Absorption SpectroMeter for Atmospheric CHartographY (SCIAMACHY) $\mathrm{NO}_{2}$ retrievals $\mathrm{NO}_{\mathrm{x}}$ emissions increases over India have been about half of those over China between 2002 and 2011.

\section{Introduction}

The boreal summer monsoon circulation over the polluted land mass of Asia vents chemical constituents from the boundary layer into the upper troposphere and lower stratosphere (UTLS), where they are re-distributed over a wide region in the subtropical latitudes (Gettelman et al., 2004; Park et al., 2004, 2007; Li et al., 2005; Randel and Park, 2006; Fu et al., 2006; Xiong et al., 2009; Randel et al., 2010; Fadnavis et al., 2013). The chemical constituents in the UTLS influence the radiative balance and heat transport in the atmosphere (Ravishankara, 2012; Fadnavis et al., 2013). For example, monsoon injection contributes $\sim 75 \%$ of the total net upward water vapor flux in the tropics at tropopause levels (Gettelman et al., 2004). The increased amount of water vapor in the lower stratosphere could enhance ozone deple- 
tion and thus raise ultraviolet radiation levels at Earth's surface (Anderson et al., 2012). Satellite observations show convective transport and mixing of chemical constituents (e.g., aerosols, $\mathrm{CO}, \mathrm{NO}_{\mathrm{x}}, \mathrm{CH}_{4}$ and $\mathrm{HCN}$ ) in the tropical tropopause region during the Asian summer monsoon (ASM) season (Dodion et al., 2008; Park et al., 2009; Randel et al., 2010; Vernier et al., 2011). In the stratosphere, these chemical constituents are transported to the southern subtropics by the Brewer-Dobson circulation (Park et al., 2004; Fadnavis et al., 2013) and they affect ozone, water vapor and aerosolrelated constituents in the global stratosphere (Randel et al., 2010; Randel and Jensen, 2013). Peroxyacetyl nitrate (PAN) is one such chemical species important in the tropical UTLS over the south Asian regions for two reasons: (1) it is a secondary pollutant with implications for the production of tropospheric ozone $\left(\mathrm{O}_{3}\right)$; (2) PAN is also a useful tracer for diagnosing transport due to monsoon convection and understand the redistribution of $\mathrm{NO}_{\mathrm{x}}$ in the global stratosphere.

PAN mixing ratios vary from less than 1 pptv in the remote marine atmosphere (as observed in NASA GTE PEM-Tropics B campaign in the South Pacific lower marine boundary layer, data available at http://acd.ucar.edu/ emmons/DATACOMP/) to several ppbv in the polluted urban environment and biomass burning plumes (Ridley et al., 1992; Singh et al., 1998). In the UTLS, mixing ratios are typically in the range 10-300 pptv (Emmons et al., 2000; Keim et al., 2008). PAN is formed exclusively from the chemical reaction of peroxyacetyl radicals $\left(\mathrm{CH}_{3} \mathrm{C}(\mathrm{O}) \mathrm{OO}\right)$ with $\mathrm{NO}_{2}$. The peroxyacetyl radical is generated from the oxidation of acetaldehyde $\left(\mathrm{CH}_{3} \mathrm{CHO}\right)$ by $\mathrm{OH}$, or through photolytic decomposition of acetone $\left(\mathrm{CH}_{3} \mathrm{COCH}_{3}\right)$ and methylglyoxal $\left(\mathrm{CH}_{3} \mathrm{COCHO}\right)$, which are secondary pollutants, produced by oxidation of other non-methane volatile organic compounds (NMVOCs) such as propene $\left(\mathrm{C}_{3} \mathrm{H}_{6}\right)$. In the upper troposphere, photolysis of acetone $\left(\mathrm{CH}_{3} \mathrm{COCH}_{3}\right)$ is an important source of peroxyacetyl radicals (Fischer et al., 2013). The main loss reactions of PAN are thermal decomposition (most important in the lower troposphere up to $\sim 500 \mathrm{hPa}$ ), photolysis (most important in the UTLS and above) and the reaction with $\mathrm{OH}$. All of these reactions lead to the formation of reactive nitrogen compounds: the first two reactions yield $\mathrm{NO}_{2}$, while the reaction with $\mathrm{OH}$ yields $\mathrm{NO}_{3}$ as a product. At the surface, PAN can also be deposited. Its dry deposition velocity is on the order of $0.5 \mathrm{~cm} \mathrm{~s}^{-1}$ during daytime and $0.1 \mathrm{~cm} \mathrm{~s}^{-1}$ during nighttime (Wu et al., 2012).

Rapid industrialization, traffic growth and urbanization in Asia cause increasing emissions of ozone precursors including $\mathrm{NO}_{\mathrm{x}}$ and VOCs. These emissions are projected to increase through 2020 in spite of the efforts of Asian countries to combat air pollution problems (Ohara et al., 2007). Most parts of Asia are $\mathrm{NO}_{\mathrm{x}}$ limited regions, i.e., controlling $\mathrm{NO}_{\mathrm{x}}$ in these regions would reduce ozone concentrations (Yamaji et al., 2006; Sinha et al., 2014). India and China are by far the largest emitters in Asia. Satellite observations by the SCanning Imaging Absorption SpectroMeter for Atmo- spheric CHartographY (SCIAMACHY) and Ozone Monitoring Instrument (OMI) exhibit positive trends of $\sim 3.8 \% \mathrm{yr}^{-1}$ in tropospheric column $\mathrm{NO}_{2}$ over India (Ghude et al., 2013) and $7.3( \pm 3.1) \% \mathrm{yr}^{-1}$ over China (Schneider and van der $A, 2012)$. Although there is debate if these observed $\mathrm{NO}_{\mathrm{x}}$ changes could be directly related to emission changes, there is no doubt that increased $\mathrm{NO}_{\mathrm{x}}$ concentrations can enhance the formation of PAN, some of which is then transported into the UTLS by the Asian summer monsoon (ASM) circulation. In addition to PAN being transported from the polluted boundary layer, it can also be formed in the upper troposphere through the production of $\mathrm{NO}_{\mathrm{x}}$ from lightning (Tie et al., 2001; Zhao et al., 2009). Lightning activity over southern Asia is highest during the monsoon season (Ranalkar and Chaudhari, 2009; Penki and Kamra 2013). The estimated global $\mathrm{NO}_{\mathrm{x}}$ production by lightning is $\sim 3 \mathrm{Tg} \mathrm{N} \mathrm{yr}^{-1}$ (Nesbitt et al., 2000; Tie et al., 2002). Simulations with the model of ozone and related tracers (MOZART) show an increase in UTLS PAN over the ASM region due to lightning by 20$30 \%$ (Tie et al., 2001).

Thus it is interesting to examine the influence of Asian monsoon convection on the distribution of PAN in the global UTLS. Also, the impact of enhanced $\mathrm{NO}_{\mathrm{x}}$ emissions from India and China on the redistribution of PAN and other related chemical species in the global UTLS merits attention. Due to the $\mathrm{NO}_{\mathrm{x}}$ limitation in India and China, the impact of enhanced VOC emissions on the distribution of PAN is expected to be smaller. Investigating this in more detail goes beyond the scope of this study because one would have to define a credible VOC speciation and its changes over time. We employ the state-of-the-art ECHAM5-HAMMOZ (European Centre General Circulation Model version5, ECHAM5, aerosols Hamburg Module, HAM, and chemistry from MOZART-2, MOZ) chemistry climate model (Roeckner et al., 2003; Horowitz et al., 2003; Stier et al., 2005) and perform sensitivity simulations in order to investigate the relative contributions from India and China to the increased UTLS PAN concentrations. The paper is organized as follows: data analysis, model description and setup are described in Sect. 2. In Sect. 3, we discuss the distribution of PAN in the UTLS during the ASM from satellite measurements and its transport from model simulations. Section 4 contains satellite-observed trends in PAN over India and China. The impact of enhanced anthropogenic Asian $\mathrm{NO}_{\mathrm{x}}$ on $\mathrm{PAN}, \mathrm{HNO}_{3}$ and ozone are discussed in Sect. 5. Conclusions are given in Sect. 6.

\section{Data and analysis}

\subsection{Satellite measurement}

The MIPAS-E instrument onboard the ENVIronmental SATellite (ENVISAT) was launched in March 2002 into a polar orbit of $800 \mathrm{~km}$ altitude, with an orbital period of 
about $100 \mathrm{~min}$ and an orbit repeat cycle of 35 days. MIPASE (Fischer and Oelhaf, 1996; Fischer et al., 2008) was a Fourier transform spectrometer that provided continual limb emission measurements in the mid-infrared over the range $685-2410 \mathrm{~cm}^{-1}(14.6-4.15 \mu \mathrm{m})$. From June 2002 to March 2004, MIPAS operated in its full spectral resolution mode at an un-apodized resolution of $0.035 \mathrm{~cm}^{-1}$, and with tangent altitude steps of $3 \mathrm{~km}$ in the UTLS. From January 2005 through the end of the mission the spectral resolution was reduced to $0.0875 \mathrm{~cm}^{-1}$, while the tangent altitude steps in the UTLS were reduced to $1.5-2 \mathrm{~km}$. Until the platform's failure in April 2012, MIPAS monitored atmospheric minor constituents affecting atmospheric chemistry including PAN, $\mathrm{NO}_{X}$ and $\mathrm{O}_{3}$. The details of the general retrieval method and setup, error estimates and use of averaging kernel and visibility flag are documented by Von Clarmann et al. (2009). Details of the PAN retrievals, error budget and vertical resolution are given by Glatthor et al. (2007) for the 2002-2004 measurement period for data version V3O_PAN_5, and by Wiegele et al. (2012) for the 2005-2012 measurement period for data version V5R_PAN_220/V5R_PAN_221 (different 220/221 naming due to technical reasons). The total error of PAN retrievals is below $20 \%$ from $10-12 \mathrm{~km}$, below $30 \%$ from $12-16 \mathrm{~km}$ and below $40 \%$ above $16 \mathrm{~km}$ for V3O_PAN_5 (see Fig. 2 in Glatthor et al., 2007). The error is dominated by contributions of spectral noise and the uncertainty of the instrument pointing. Table 3 in Wiegele et al. (2012) indicates that for the V5R_PAN_220/221 product, the total error is below $10 \%$ from $10-12 \mathrm{~km}$ and above $100 \%$ for altitudes greater than $15 \mathrm{~km}$. Again, spectral noise and the uncertainty of the instrument pointing are the main contributors.

The sensitivity of the PAN retrievals can be judged by the averaging kernels. Since two types of retrievals are used in this study, V3O_PAN_5 and V5R_PAN_220/221 from high and reduced spectral resolution, respectively, we give two examples of the respective averaging kernel rows. The locations of the examples are $26^{\circ} \mathrm{N}$ and $81^{\circ} \mathrm{E}$ for the V3O_PAN_5 example and $28^{\circ} \mathrm{N}$ and $85^{\circ} \mathrm{E}$ for V5R_PAN_220. Figure S1a and $b$ in the Supplement shows the rows of the averaging kernels for an altitude range of 5 to $25 \mathrm{~km}$. The diamonds indicate the respective nominal altitudes of the retrieval grid. Figure S1 in the Supplement shows that the retrieval results below $8-9 \mathrm{~km}$ are dominated by information from above the nominal altitude. A similar, albeit less obvious, situation develops for altitudes above $22-23 \mathrm{~km}$. There and above the information has an increasing weight from lower than nominal altitudes. This is the reason why the MIPAS PAN data is not considered below $8 \mathrm{~km}$ and above $23 \mathrm{~km}$. Another effect clearly visible in both example plots is that the altitude region which influences the retrieved PAN value at a given altitude is increasing with altitude, i.e., the vertical resolution decreases with altitude. To account for the comparatively low and altitude-dependent vertical resolution, the model data to be directly compared to MIPAS measurements was convolved with the MIPAS PAN averaging kernel.

In this study we analyze the MIPAS-E-observed PAN data during the period 2002-2011. The data can be accessed at http://share.lsdf.kit.edu/imk/asf/sat/mipas-export/ Data_by_Target/. The data versions used are V3O_PAN_5 for 2002-2004, and V5R_PAN_220/V5R_PAN_221 for 2005-2011. The data is processed as per the quality specifications given in the documentation. The useful height range is specified as 5 to $23 \mathrm{~km}$. The data are contoured and gridded at $8^{\circ}$ longitude and $4^{\circ}$ latitude resolution.

\subsection{ECHAM5-HAMMOZ model simulation and experimental setup}

The ECHAM5-HAMMOZ aerosol-chemistry-climate model used in the present study comprises of the general circulation model ECHAM5 (Roeckner et al., 2003), the tropospheric chemistry module, MOZ (Horowitz et al., 2003) and the aerosol module, Hamburg Aerosol Model (HAM) (Stier et al., 2005). The gas phase chemistry is based on MOZART-2 model (Horowitz et al., 2003) chemical scheme, which includes a detailed chemistry of $\mathrm{O}_{\mathrm{x}}-\mathrm{NO}_{\mathrm{x}}$ hydrocarbons with 63 tracers and 168 reactions. The radiative transfer calculation considers the simulated concentrations of both ozone and aerosols. The $\mathrm{O}\left({ }^{1} \mathrm{D}\right)$ quenching reaction rates were updated according to Sander et al. (2003), and the isoprene nitrates chemistry according to Fiore et al. (2005). In the MOZART chemical mechanism, the PAN formation process occurs through the reaction of peroxyacetyl radical $\left(\mathrm{CH}_{3} \mathrm{CO}_{3}\right)$ and $\mathrm{NO}_{2}$. This reaction is reversible, and the thermal decomposition of PAN back to $\mathrm{CH}_{3} \mathrm{CO}_{3}$ and $\mathrm{NO}_{2}$ is the main sink of PAN. The reaction rates for this reversible reaction are updated according to Sander et al. (2006). $\mathrm{CH}_{3} \mathrm{CO}_{3}$ is mainly formed by oxidation of acetaldehyde $\left(\mathrm{CH}_{3} \mathrm{CHO}\right)$ by $\mathrm{OH}$, and by the photolytic decomposition of acetone $\left(\mathrm{CH}_{3} \mathrm{COCH}_{3}\right)$ and methylglyoxal $\left(\mathrm{CH}_{3} \mathrm{COCHO}\right)$. In the model simulations, we included emissions of acetone from anthropogenic sources and wild fires (primary sources), while acetaldehyde and methylglyoxal are produced by the oxidation of other NMVOCs (secondary sources). In particular, oxidation of primary NMVOCs like ethane $\left(\mathrm{C}_{2} \mathrm{H}_{6}\right)$, propane $\left(\mathrm{C}_{3} \mathrm{H}_{8}\right)$ and propene $\left(\mathrm{C}_{3} \mathrm{H}_{6}\right)$ forms acetaldehyde, while $\mathrm{CH}_{3} \mathrm{COCHO}$ is mainly formed from the oxidation products of isoprene and terpenes. Higher acyl peroxy nitrates (MPAN) are included in MOZART-2 chemical scheme, they are also formed through oxidation of NMVOCs, but their production is not significant compared to PAN. The main loss process of PAN from the atmosphere is the thermal decomposition into its precursors. Other loss processes are photolysis and reaction with $\mathrm{OH}$. In ECHAM5-HAMMOZ, dry deposition follows the scheme of Ganzeveld and Lelieveld (1995). Soluble trace gases such as $\mathrm{HNO}_{3}$ and $\mathrm{SO}_{2}$ are also subject to wet deposition. In-cloud and below-cloud scavenging follows the scheme described 


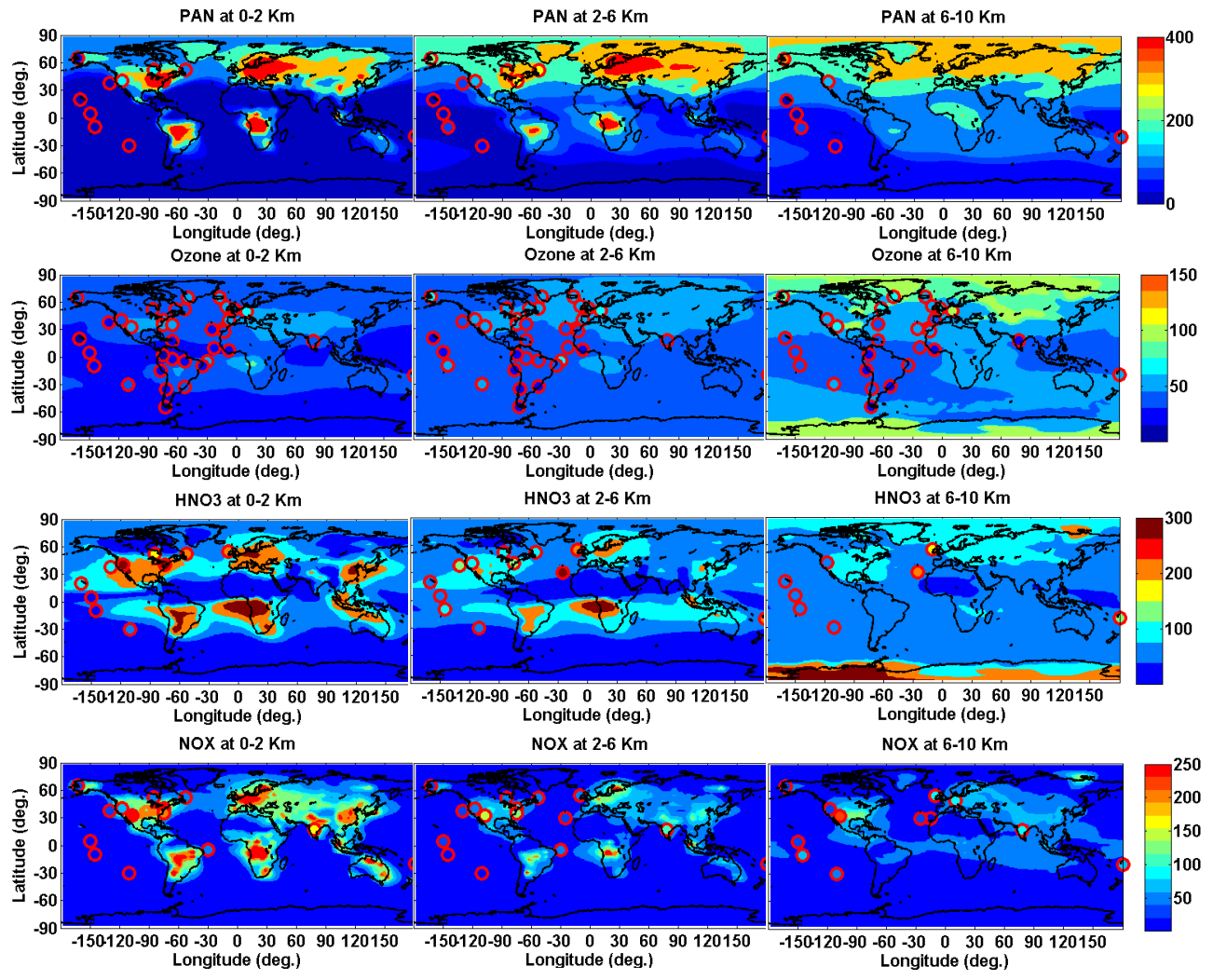

Figure 1. Global mean distribution of PAN (ppt), ozone (ppb), $\mathrm{HNO}_{3}\left(\mathrm{ppt}\right.$ ) and $\mathrm{NO}_{\mathrm{x}}(\mathrm{ppt}$ ) averaged for the monsoon season and altitude ranges. Model results from reference simulation (background solid contours) are compared with aircraft observations from Table 1 for all the years (filled circles). Aircraft observations are averaged vertically and horizontally over the coherent regions.

by Stier et al. (2005). PAN is not highly water soluble, therefore wet deposition is a minor removal process, and dry deposition is also not significant.

The model is run at a spectral resolution of T42 corresponding to about $2.8^{\circ} \times 2.8^{\circ}$ in the horizontal dimension and 31 vertical hybrid $\sigma-p$ levels from the surface up to $10 \mathrm{hPa}$. The details of model parameterizations, emissions and validation are described by Fadnavis et al. (2013), Pozzoli et al. (2008a, b, 2011). Here, we note that our base year for aerosol and trace gas emissions is 2000. Each member of our sensitivity study consists of continuous simulations for 10 years from 1995 to 2004. Emissions were the same in each simulation, and meteorology varied because of different sea surface temperature (SST) and sea ice (SIC) data. The AMIP2 SSTs and SIC representative of the period 19952004 were specified as a lower boundary condition.

In order to understand the impact of enhanced anthropogenic $\mathrm{NO}_{\mathrm{x}}$ emissions on the distributions of PAN, $\mathrm{HNO}_{3}$ and ozone in the UTLS, we conducted six simulations for the period 1995-2004: (1) a reference experiment and five sensitivity experiments (referred to as experiments 2-6), where $\mathrm{NO}_{\mathrm{x}}$ emissions over India and China were scaled according to the observed trends. Experiment (2) increases $\mathrm{NO}_{\mathrm{x}}$ emissions over India by $38 \%$ (Ind38), run (3) increases those over China by $73 \%$ (Chin73). Experiment (4) shows the effect of the combined changes (India by $38 \%$, China by $73 \%$ ) (Ind38Chin73). Experiment (5) assumes equal relative changes of $\mathrm{NO}_{\mathrm{x}}$ emissions (India by $38 \%$, China by $38 \%$ (Ind38Chin38)) in order to analyze the respective contributions, and to understand the regional emission enhancement impact on the UTLS for same emission enhancement over China. In experiment (6), emissions are increased over India by $73 \%$ (Ind73) to analyze the impact of Indian emissions with equal emissions from China. The emission perturbations were derived from observed $\mathrm{NO}_{2}$ trends of $\sim 3.8 \%$ per year over India (Ghude et al., 2013) and $7.3( \pm 3.1) \%$ per year over China (Schneider and van der A, 2012). Similar values of $\mathrm{NO}_{2}$ trends $\left(5-10 \% \mathrm{yr}^{-1}\right)$ are also reported by Hilboll et al. (2013) over megacities of India and China.

\section{Results and discussions}

\subsection{Comparison with aircraft and ozonesonde measurements}

Model-simulated PAN, $\mathrm{NO}_{\mathrm{x}}, \mathrm{HNO}_{3}$ and Ozone mixing ratios are evaluated with climatological datasets of airborne campaigns during the monsoon season (June-September). 
Table 1. Global aircraft measurements used for model evaluation.

\begin{tabular}{|c|c|c|c|}
\hline Experiment & Date frame & Species & Location \\
\hline POLINAT-2 (Falcon) & Sep 19-Oct 25, 1997 & $\mathrm{O}_{3}, \mathrm{NO}_{\mathrm{x}}$ & $\begin{array}{l}\text { Canary Islands: lat }=25,35 \text { long }=340,350 \\
\text { Eastern Atlantic: lat }=35,45 \text { long }=330,340 \\
\text { Europe: lat }=45,55 \text { long }=5,15 \\
\text { Ireland: lat }=50,60 \text { long }=345,355\end{array}$ \\
\hline PEM-Tropics-A (DC8) & Aug 24-Oct 15, 1996 & $\mathrm{O}_{3}, \mathrm{NO}_{\mathrm{x}}, \mathrm{HNO}_{3}, \mathrm{PAN}$ & $\begin{array}{l}\text { Christmas Island: lat }=0,10 \text { long }=200,220 \\
\text { Easter Island: lat }=-40,-20 \text { long }=240,260 \\
\text { Fiji: lat }=-30,-10 \text { long }=170,190 \\
\text { Hawaii: lat }=10,30 \text { long }=190,210 \\
\text { Tahiti: lat }=-20,0 \text { long }=200,230\end{array}$ \\
\hline PEM-Tropics-A (P3) & Aug 15-Sep 26, 1996 & $\mathrm{O}_{3}, \mathrm{HNO}_{3}$ & $\begin{array}{l}\text { Christmas Island: lat }=0,10 \text { long }=200,220 \\
\text { Easter Island: lat }=-40,-20 \text { long }=240,260 \\
\text { Hawaii: lat }=10,30 \text { long }=190,210 \\
\text { Tahiti: lat }=-20,0 \text { long }=200,230\end{array}$ \\
\hline ABLE-3B (Electra) & Jul 6-15, 1990 & $\mathrm{O}_{3}, \mathrm{NO}_{\mathrm{x}}, \mathrm{HNO}_{3}, \mathrm{PAN}$ & $\begin{array}{l}\text { Labrador: lat }=50,55 \text { long }=300,315 \\
\text { Ontario: } 1 \text { lat }=45,60 \text { long }=270,280 \\
\text { US East Coast: lat }=35,45 \text { long }=280,290\end{array}$ \\
\hline CITE-3 (Electra) & Aug 22-Sep 29, 1989 & $\mathrm{O}_{3}, \mathrm{NO}_{\mathrm{x}}$ & $\begin{array}{l}\text { Natal: lat }=-15,5 \text { long }=325,335 \\
\text { Wallops: lat }=30,40 \text { long }=280,290\end{array}$ \\
\hline ELCHEM (Sabreliner) & Jul 27-Aug 22, 1989 & $\mathrm{O}_{3}, \mathrm{NO}_{\mathrm{x}}$ & New Mexico: lat $=30,35$ long $=250,255$ \\
\hline ABLE-3A (Electra) & Jul 7-Aug 17, 1988 & $\mathrm{O}_{3}, \mathrm{NO}_{\mathrm{x}}, \mathrm{PAN}$ & Alaska: lat $=55,75$ long $=190,205$ \\
\hline ABLE-2A (Electra) & Jul 12-Aug 13, 1985 & $\mathrm{O}_{3}$ & $\begin{array}{l}\text { Eastern Brazil: lat }=-10,0 \text { long }=300,315 \\
\text { Western Brazil: lat }=-5,0 \text { long }=290,300\end{array}$ \\
\hline STRATOZ-3 (Caravelle 116) & Jun 4-26, 1984 & $\mathrm{O}_{3}$ & $\begin{array}{l}\text { Brazil: lat }=-20,0 \text { long }=315,335 \\
\text { Canary Islands: lat }=20,35 \text { long }=340,355 \\
\text { E Tropical N Atlantic: lat }=0,20 \text { long }=330,345 \\
\text { England: lat }=45,60 \text { long }=-10,5 \\
\text { Goose Bay: lat }=45,60 \text { long }=290,305 \\
\text { Greenland: lat }=60,70 \text { long }=290,330 \\
\text { Iceland: lat }=60,70 \text { long }=330,355 \\
\text { NW South America: lat }=-5,10 \text { long }=275,295 \\
\text { Puerto Rico: lat }=10,25 \text { long }=290,300 \\
\text { S South America: lat }=-65,-45 \text { long }=275,300 \\
\text { SE South America: lat }=-45,-20 \text { long }=295,320 \\
\text { SW South America: lat }=-45,-25 \text { long }=285,292 . \\
\text { Spain: lat }=35,45 \text { long }=-15,0 \\
\text { West Africa: lat }=0,15 \text { long }=-15,0 \\
\text { W South America: lat }=-25,-5 \text { long }=275,290 \\
\text { Western N Atlantic: lat }=25,45 \text { long }=290,300\end{array}$ \\
\hline CITE-2 (Electra) & Aug 11-Sep 5, 1986 & $\mathrm{O}_{3}, \mathrm{NO}_{\mathrm{x}}, \mathrm{HNO}_{3}, \mathrm{PAN}$ & $\begin{array}{l}\text { California lat }=35,45 \text { long }=235,250 \\
\text { Pacific: lat }=30,45 \text { long }=225,235\end{array}$ \\
\hline CAIPEEX & Sep 2009 and Oct 2010 & $\mathrm{O}_{3}, \mathrm{NO}_{\mathrm{x}}$ & lat $=17^{\circ} \mathrm{N}$, long $=78^{\circ} \mathrm{E}$ \\
\hline
\end{tabular}

The data were retrieved from http://acd.ucar.edu/ emmons/ DATACOMP/CAMPAIGNS/. The $\mathrm{NO}_{\mathrm{x}}$ and ozone volume mixing ratios observed during Cloud Aerosol Interaction \& Precipitation Enhancement Experiment (CAIPEEX) experiment, September 2010, are evaluated over the Indian region. The details of instrument and measurement techniques are available at http://www.tropmet.res.in/ caipeex/about-data. php. The list of data sets and aircraft campaigns are presented in Table 1. For comparison, aircraft observations are averaged over $0-2 \mathrm{~km}, 2-6 \mathrm{~km}$ and $6-8 \mathrm{~km}$ and at the coherent latitude and longitude of the flight region. Model simulations are also averaged at the same altitudes. Figure $1 \mathrm{a}-\mathrm{k}$ com- pare the observed global distribution of PAN, ozone, $\mathrm{HNO}_{3}$ and $\mathrm{NO}_{\mathrm{x}}$ to those simulated by ECHAM5-HAMMOZ. The mean aircraft observations are shown as filled circles and model output are background contours. Figure 1 indicates that model-simulated $\mathrm{PAN}, \mathrm{HNO}_{3}$ and $\mathrm{NO}_{\mathrm{x}}$ show good agreement with aircraft measurements. Figure $\mathrm{S} 2$ in the Supplement indicates the model bias (ECHAM5-HAMMOZ aircraft observations) in PAN, ozone, $\mathrm{HNO}_{3}$ and ozone. The model bias is different at each location. It varies with species and altitude. Between 0 and $2 \mathrm{~km}$, simulated PAN shows positive bias 7-12 ppt in the western Pacific, 52-105 ppt over the United States of America (USA). Ozone shows positive 

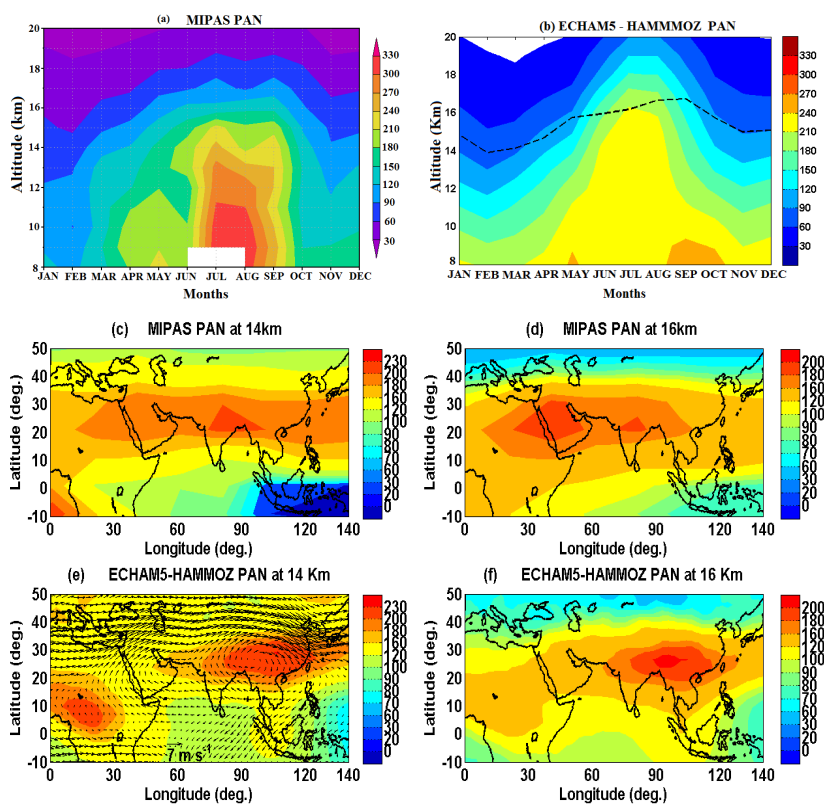

Figure 2. The monthly distribution of PAN (ppt) averaged over the anticyclone region $\left(60-120^{\circ} \mathrm{E}, 10-40^{\circ} \mathrm{N}\right)($ a) as observed by MIPAS and for the period 2002-2011 (b) ECHAM5-HAMMOZ reference simulation. Distribution of seasonal mean PAN concentration (ppt) as observed by MIPAS (climatology for the period 20022011) at (c) $14 \mathrm{~km}$ (d) $16 \mathrm{~km}$ and ECHAM5-HAMMOZ reference simulation at (e) $14 \mathrm{~km}$ (f) $16 \mathrm{~km}$. ECHAM5-HAMMOZ simulation is smoothed with averaging kernel of MIPAS.

bias $\sim 7 \mathrm{ppb}$ over India, $\sim 3-15 \mathrm{ppb}$ over the western Pacific, negative bias $\sim 2-20 \mathrm{ppb}$ in mid-latitude Atlantic and positive bias $2-20 \mathrm{ppb}$ over tropical Atlantic, $\sim 2-18 \mathrm{ppb}$ over the USA. $\mathrm{HNO}_{3}$ is higher by $\sim 20-75$ ppt over the western Pacific and lower by $\sim-5 \mathrm{ppt}$ at few locations. Over the USA bias is negative less than 5 ppt. $\mathrm{NO}_{\mathrm{x}}$ shows positive bias $\sim 40$ ppt over India and $0-10$ ppt over the western Pacific. Between 2-6 m and 6-10 km, over the western Pacific simulated PAN show negative bias $\sim 10-20$ ppt and positive bias $\sim 5-50 \mathrm{ppt}$ at some locations. Over the USA bias values are $\sim 4-70$ ppt. Ozone is lower by $\sim 10-15 \mathrm{ppb}$ and higher by $\sim 3-30 \mathrm{ppb}$ at some locations in the western Pacific, 3-30 ppb over Atlantic and $\sim 2-30 \mathrm{ppb}$ over the USA. The positive bias in $\mathrm{HNO}_{3}$ reduces to $3-20 \mathrm{ppt}$ and negative bias to 3 to $20 \mathrm{ppt}$ over the western Pacific, over the USA negative bias is $\sim 20 \mathrm{ppt}$ and positive bias is $\sim 3-70 \mathrm{ppt}$. The $\mathrm{NO}_{\mathrm{x}}$ shows negative bias $\sim 40$ ppt over India. The bias values vary between 6 and 10 ppt over the western Pacific, 15 and -20 ppt over the USA and Atlantic. As can be seen from above discussions, ozone exhibits a low bias over South America and the Atlantic (for 0-6 km). Model-simulated ozone and $\mathrm{NO}_{\mathrm{x}}$ show good agreement with CAIPEEX measurements over the Indian region. Model-simulated seasonal mean ozone is compared with ozonesonde measurements (2000-2009) over three distributed stations, where verti- cal profiles are available for long periods (1) near equator (Thiruvananthapuram: $8.4875^{\circ} \mathrm{N}, 76.9525^{\circ} \mathrm{E},(2)$ tropical (Pune: $18.52^{\circ} \mathrm{N}, 73.85^{\circ} \mathrm{E}$ ) and (3) subtropical stations (Delhi: $28.61^{\circ} \mathrm{N}, 77.23^{\circ} \mathrm{E}$ ) over India. The simulated ozone profiles are extracted at the grid square nearest the center of the above three stations. Figure S3 in the Supplement depicts that simulated ozone show fairly good agreement with ozonesonde measurements over all the three stations: in general, simulated ozone is less than that of ozonesonde measurements except at Delhi (between 200 and $100 \mathrm{hPa}$ ). At Delhi, simulated ozone is less than that ozonesonde by $\sim 3-40 \mathrm{ppb}$ in the troposphere and by $1000-4000 \mathrm{ppb}$ in the lower stratosphere. The differences are larger at Pune (troposphere $\sim 20-120 \mathrm{ppb}$, stratosphere $\sim 900-2500 \mathrm{ppb}$ ) and lesser at Thiruvananthapuram (troposphere $\sim 10-30 \mathrm{ppb}$ and stratosphere $300-1300 \mathrm{ppb}$ ). This may be due to differences in spatial coverage. The ozonesonde measurements are at the stations (although ozonesonde drifts horizontally) while model simulations are made at the grid square $\left(2.8^{\circ} \times 2.8^{\circ}\right)$ nearest to the station.

\subsection{Transport of PAN into the UTLS due to monsoon convection}

Figure 2a shows the vertical distribution during the annual cycle of the MIPAS-E PAN climatology (for the period 2002-2011) averaged over the ASM region $\left(10-40^{\circ} \mathrm{N} ; 60\right.$ $120^{\circ}$ E). ECHAM5-HAMMOZ-simulated PAN mole fractions are smoothed with the averaging kernel of MIPAS. The monthly distribution clearly shows elevated levels of PAN in the UTLS during the ASM season (June-September). Seasonal variation of ECHAM5-HAMMOZ simulated PAN (obtained from reference experiment) over this region is plotted in Fig. 2b for comparison. It also indicates plumes rising into the UTLS during the ASM season, although PAN mole fractions are less than those obtained from MIPAS-E especially during July and August. These differences may be due to uncertainties in $\mathrm{VOC}, \mathrm{NO}_{\mathrm{x}}$ emissions, chemistry represented in the model, transport errors and coarse model resolution. Also, MIPAS-E views the atmosphere from above and there are uncertainties in the MIPAS-E retrievals. The cross-section plots of differences in MIPAS-E PAN with model-simulated PAN (see Fig. S4 in the Supplement) indicate that in the UTLS $(8-23 \mathrm{~km})$, MIPAS-E PAN is higher than model-simulated PAN by $\sim 20-60 \mathrm{ppt}$ (except above $20 \mathrm{~km}$ ). It is lower by $20-40$ ppt over the eastern part of anticyclone (southern India and southeast Asia) and 20-40 ppt over Indonesia and northern Australia. Near the South Pole, MIPAS-E PAN is higher than in ECHAM5HAMMOZ by $20-90$ ppt. The model could not produce high PAN concentrations near the South Pole between 17 and $23 \mathrm{~km}$. In general, in the ASM region during the monsoon season, MIPAS-E PAN is higher than the model by 30 $60 \mathrm{ppt}$ between 8 and $16 \mathrm{~km}$ and model biases vary between $+40 \mathrm{ppt}$ and $-40 \mathrm{ppt}$ between 17 and $23 \mathrm{~km}$. The compar- 

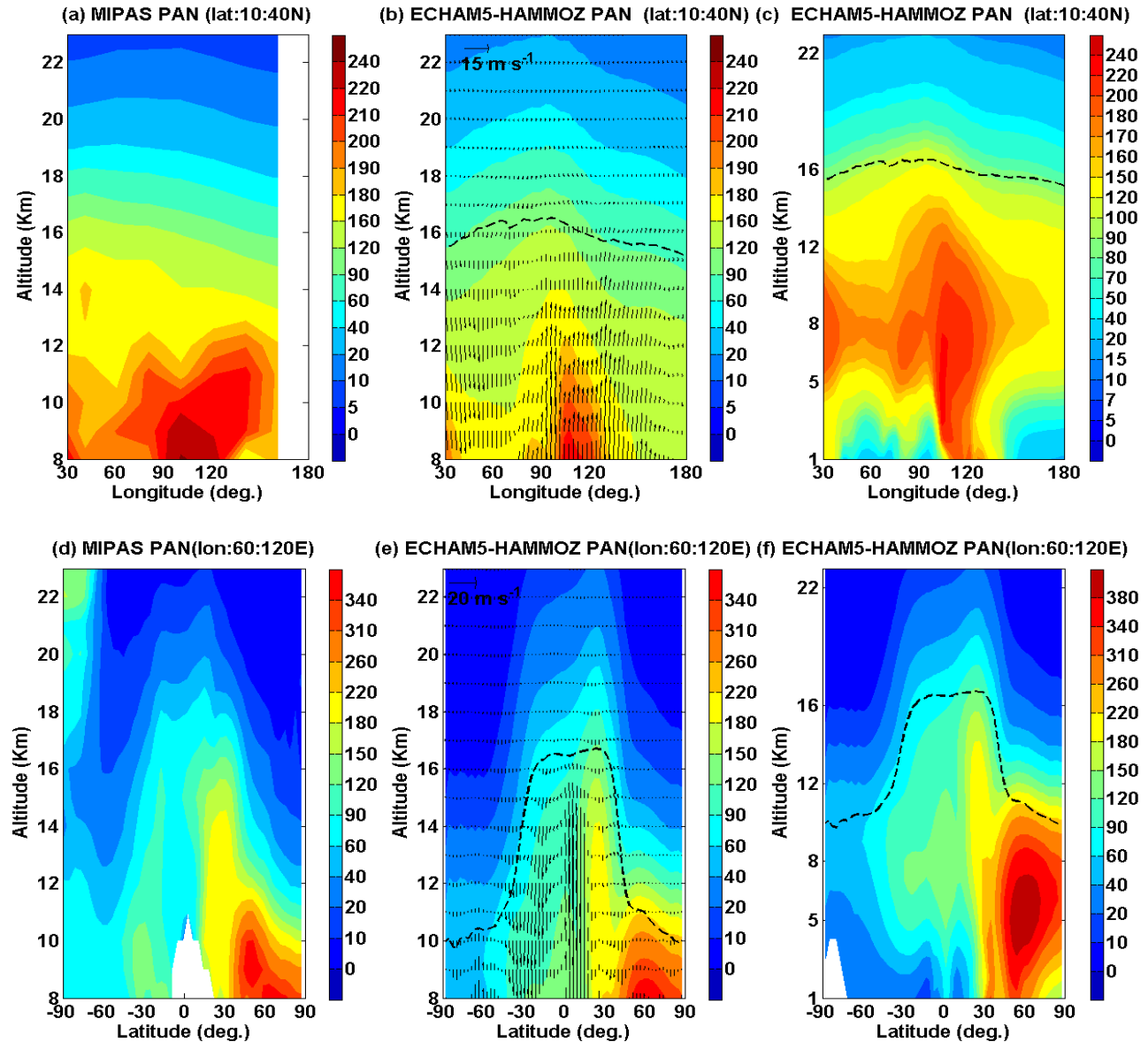

Figure 3. Longitude-altitude cross section of PAN (ppt) averaged for the monsoon season and 10-40 N: (a) MIPAS (climatology for the period 2002-2011) and (b) ECHAM5-HAMMOZ reference simulation between 8 and $23 \mathrm{~km}$. The black arrows indicate wind vectors. The vertical velocity field has been scaled by 300 . Panel (c) is the same as figure (b) but from the surface. Latitude-altitude cross section of PAN (ppt) averaged for the monsoon season and 60-120 E for (d) MIPAS climatology and (e) ECHAM5-HAMMOZ reference simulation between 8 and $23 \mathrm{~km}$; (f) same as (e) but from the surface. ECHAM5-HAMMOZ simulation is smoothed with averaging kernels of MIPAS.

ison of PAN measurements from MIPAS-E with the Atmospheric Chemistry Experiment-Fourier Transform Spectrometer (ACE-FTS) indicates MIPAS-E PAN is higher than ACE-FTS in the UTLS by $70 \mathrm{ppt}$ at the altitudes between 9.5 and $17.5 \mathrm{~km}$, which lies within limits of measurement error (Tereszchuk et al., 2013).This indicates that model-simulated PAN concentrations in the UTLS show reasonable agreement with MIPAS-E.

The observed high concentrations during the monsoon season may be due to transport from the lower troposphere due to strong convection and partially due to lightning activity. Thus, in order to study the influence of ASM circulation on the distribution of PAN in the UTLS region, the seasonal mean PAN concentrations (June-September) are analyzed. We present here estimates of the PAN climatology from MIPAS-E for the ASM season. Figure $2 \mathrm{c}$ and $\mathrm{d}$ exhibit the seasonal mean distribution of PAN as observed by MIPAS at $14 \mathrm{~km}$ and $16 \mathrm{~km}$, respectively. PAN distributions obtained from ECHAM5-HAMMOZ reference simulations at
14 and $16 \mathrm{~km}$ are plotted in Fig. 2e and f respectively for comparison. Figure $2 \mathrm{c}-\mathrm{d}$ shows maxima in PAN concentrations $(\sim 200-250 \mathrm{ppt})$ over the Asian monsoon anticyclone region $\left(12-40^{\circ} \mathrm{N}, 20-120^{\circ} \mathrm{E}\right)$. The model is able to reproduce the maximum in PAN in the monsoon anticyclone, but simulated PAN concentrations are less than MIPAS observations.

To illustrate vertical transport in the Asian monsoon region, longitude-altitude cross sections averaged over the monsoon anticyclone region $10-40^{\circ} \mathrm{N}$ and for JuneSeptember as obtained from MIPAS PAN observations and ECHAM5-HAMMOZ baseline simulations $(8-23 \mathrm{~km})$ are shown in Fig. 3a and b, respectively. Both MIPAS observations and ECHAM5-HAMMOZ simulations show elevated levels of PAN (200-250 ppt) over the foothills of the Himalayas $\left(80-100^{\circ} \mathrm{E}\right)$ and pollution sources in Europe and Asia. The vertical winds plotted in Fig. 3b show crosstropopause transport from the region $80-100^{\circ} \mathrm{E}$. Figure $3 \mathrm{c}$ reveals that the transport of boundary layer PAN to UTLS 


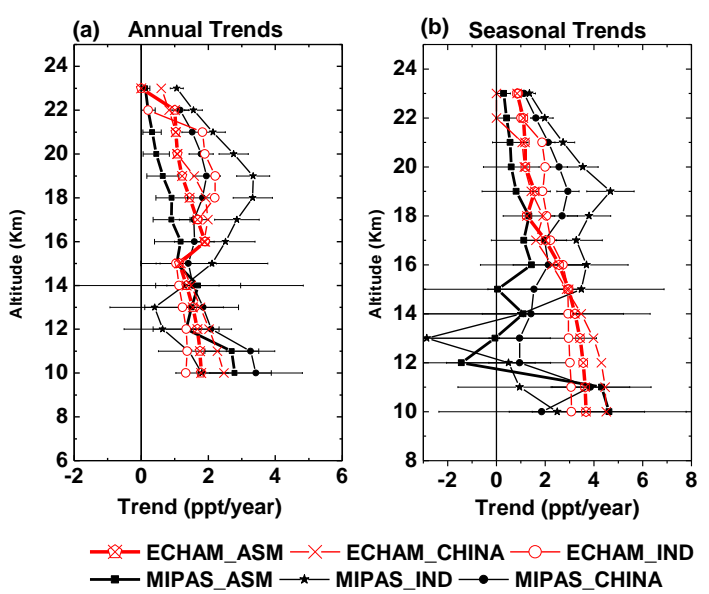

Figure 4. Vertical variation of trends obtained from monthly mean MIPAS-E PAN concentrations averaged for the period 2002-2011 and Ind38Chin73 simulations over the Asian summer monsoon, Chinese and Indian regions (a) annual trends (b) seasonal (JuneSeptember) trends.

is mainly from the strong convection regions of the South China Sea $\left(\sim 100-120^{\circ} \mathrm{E}\right)$ and southern flank of the Himalayas $\left(\sim 80-90^{\circ} \mathrm{E}\right)$. In agreement with our results, previous studies also indicate significant vertical transport due to strong monsoon convection from the southern slopes of the Himalayas (Fu et al., 2006; Fadnavis et al., 2013) and the South China Sea (Park et al., 2009). The climatology of the Advanced Very High Resolution Radiometer (AVHRR), Atmospheric Infrared Sounder (AIRS) and Moderate Resolution Imaging Spectroradiometer (MODIS) observations show frequent deep convection over the Bay of Bengal and over the foothills of the Himalayas (Devasthale and Fueglistaler, 2010). From trajectory analysis, Chen et al. (2012) reported that the three dominant regions contributing to transport from the boundary layer to the tropical tropopause are (i) the region between the tropical western Pacific and the South China Sea (38\%), (ii) the Bay of Bengal and southern Asian subcontinent (BOB, 21\%) and (iii) the Tibetan Plateau including the southern slope of the Himalayas $(12 \%)$.

The latitude-altitude cross section of MIPAS-E PAN concentrations (averaged over $60-120^{\circ} \mathrm{E}$ ) shows high levels of PAN over the northern subtropics $\left(20-40^{\circ} \mathrm{N}\right.$ ) (see Fig. 3d). The model-simulated PAN shows a similar distribution (see Fig. 3e). The simulated PAN distribution at the surface reveals that the observed high levels of PAN in the UTLS are from the subtropical boundary layer (see Fig. 3f) and are then transported upwards in deep convection. The PAN is also transported from $40-60^{\circ} \mathrm{N}$ reaching up to $16 \mathrm{~km}$. This plume is related to the biomass burning activity during this season over northeast China, Siberia, and Mongolia (figures not shown). The biomass-burning emissions estimated from satellites show intense biomass burning activity over these regions during monsoon season (Choi et al., 2013). In agreement with our results, ACE-FTS PAN measurements also shows plume concentrations $>280 \mathrm{pptv}$ rising from Siberia (Tereszchuk et al., 2013).

The boundary layer lofting of PAN by deep convection may increase $\mathrm{NO}_{\mathrm{x}}$ and hence change the ozone concentrations in the UTLS and at remote locations, where it gets transported by the Brewer-Dobson circulation (Randel et al., 2010). Another model simulation study indicates that PAN increases ozone production by removing $\mathrm{NO}_{\mathrm{x}}$ from regions of low ozone production efficiency and injecting it into regions with higher ozone production efficiency, resulting in a global increase in ozone production of $2 \%$ (Walker et al., 2010). The strong lightning activity during the monsoon season (Ranalkar and Chaudhari, 2009; Penki and Kamra, 2013) enhances the concentrations of PAN species through production of $\mathrm{NO}_{\mathrm{x}}$ (Tie et al., 2001, 2002; Labrador et al., 2005; Zhao et al., 2009; Cooper et al., 2009), which is released into a background atmosphere with some traces of VOCs. MOZART model simulations show that lightning enhances PAN emissions by $\sim 20-30 \%$ and $\mathrm{HNO}_{3}$ by $\sim 60-80 \%$ in the middle troposphere (Tie et al., 2001). ECHAM5-HAMMOZ simulations show lightning increase in $\mathrm{NO}_{\mathrm{x}}$ of $\sim 50-70 \%$, $\mathrm{O}_{3} \sim 20-35 \%, \mathrm{HNO}_{3} \sim 50-75 \%$ and $\mathrm{PAN} \sim 20-35$ over the ASM, respectively (Fadnavis et al., 2014).

\section{Trends in PAN in the UTLS of ASM region}

Trends in PAN have been computed from MIPAS-E observation in the UTLS $(8-23 \mathrm{~km})$, over the ASM region (10$\left.40^{\circ} \mathrm{N}, 60-120^{\circ} \mathrm{E}\right)$, India $\left(8-35^{\circ} \mathrm{N}, 70-94^{\circ} \mathrm{E}\right)$ and China $\left(20-45^{\circ} \mathrm{N}, 85-130^{\circ} \mathrm{E}\right)$. The trends are estimated with the method presented by Von Clarmann et al. (2010). To estimate vertical profiles of annual and seasonal trends, we took into account altitude dependent fit parameters: (1) a possible bias between the PAN values of the 2002-2004 and 2005-2011 measurement periods (details are documented by Von Clarmann et al., 2010), (2) amplitude and phase of the quasi-biennial oscillation (QBO) and (3) amplitudes and phases of periodic variations with periods of 3, 4, 6 and 12 months. The estimated trends are not significant at the altitudes between $8 \mathrm{~km}$ and $9 \mathrm{~km}$ due to the small number of data points. The trends from model simulations are calculated from the difference between Ind38Chin 73 and reference simulations. The estimated annual and seasonal trends are shown in Fig. 4a and b, respectively. Model-simulated and MIPAS-E-observed PAN in the UTLS shows positive trends. The trends obtained from MIPAS-E observations are statistically significant at $2 \sigma$ (except at few altitudes). The annual trends in MIPASE PAN vary between $0.1 \pm 0.05$ and $2.7 \pm 0.8 \mathrm{ppt} \mathrm{yr}^{-1}$ over the ASM region, $0.4 \pm 1.3-3.2 \pm 0.49 \mathrm{pptyr}^{-1}$ over India and $1.1 \pm 0.25-3.4 \pm 1.3 \mathrm{pptyr}^{-1}$ over China. Trends over India are insignificant between 12 and $14 \mathrm{~km}$. Figure $4 \mathrm{a}$ 
shows that in the upper troposphere $(10-14 \mathrm{~km})$, trends are higher over China as compared to India. In general, the trend values are higher near the tropopause $(\sim 18-19 \mathrm{~km})$. The trends computed from model simulations are of smaller values than the trends obtained from MIPAS-E observations. This may be due to the fact that the simulations do not account for any increase in VOC emissions. However, they show similar regional variations. The model estimated trends over the ASM region vary between 0.1 and $1.9 \mathrm{ppt} \mathrm{yr}^{-1}$, India $\sim 0.2-2.2$ ppt yr $^{-1}$ and China $\sim 0.8-2.4$ ppt yr $^{-1}$. The increases in transportation, industrialization and the number of coal-burning power plants result in the increase of $\mathrm{NO}_{\mathrm{x}}$ over southern and eastern Asia. The satellite-observed positive trends of $\mathrm{NO}_{\mathrm{x}}$ emissions over these regions (Ghude et al., 2013; Schneider and van der A, 2012) show coherence with estimated trends in MIPAS-E PAN. The estimated trends in MIPAS-E PAN during the monsoon season are larger than annual trends at the altitude above $16 \mathrm{~km}$ for all the three regions. At the altitudes below $14 \mathrm{~km}$, seasonal trends are less than annual trends.

During the monsoon season, the estimated trends are positive and statistically significant at $2 \sigma$. Over India the seasonal trends in MIPAS-E PAN vary between $0.5 \pm 0.8$

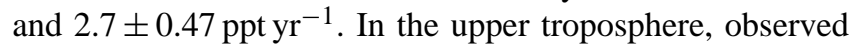
trends are statistically insignificant and they are negative between 12 and $14 \mathrm{~km}$. The trends are higher over China than India varying between $0.95 \pm 1.2$ and $2.9 \pm 0.45 \mathrm{ppt} \mathrm{yr}^{-1}$, indicating that Chinese emissions contribute more to the anticyclone. The statistically insignificant positive and negative trends in the upper troposphere over India may be related to convective transport and removal of $\mathrm{NO}_{\mathrm{x}}$ by wet scavenging in the region near the southern part of Himalayas (Fadnavis et al., 2014). Model simulations for enhanced $\mathrm{NO}_{\mathrm{x}}$ emissions over India show a nonlinear increase in PAN in the upper troposphere (see the discussions in Sect. 5.3). The variation of trends during the monsoon season computed from ECHAM5-HAMMOZ PAN is similar to the trends obtained from MIPAS-E PAN although the estimated trends are lower. Trends vary in the ranges of $\sim 0.9-3 \mathrm{ppt} \mathrm{yr}^{-1}$ over India, $\sim 1-$ $4.5 \mathrm{ppt} \mathrm{yr}^{-1}$ over China and $\sim 0.8-3.6 \mathrm{ppt} \mathrm{yr}^{-1}$ over ASM.

Trends are larger over China than India in the upper troposphere and vice versa in the lower stratosphere. The $73 \%$ change in emissions over China involves larger total emissions than the $38 \%$ change over India since China emits more than India. Most of the Indian emissions are lofted to higher altitudes than the Chinese emissions by the deep convective system at the southern slopes of the Himalayas. However, a fraction of the Chinese emissions are lofted via this convective transport as well. The role of relatively shallower convective systems in lofting Chinese emissions is greater compared to India (details are given in Sect. 5). Satellite observations show higher tropospheric $\mathrm{NO}_{\mathrm{x}}$ concentrations over China compared to India (Schneider and van der A, 2012; Ghude et al., 2013). Because of higher absolute $\mathrm{NO}_{\mathrm{x}}$ concentrations over China, the same percent change in emis- sions will lead to a larger PAN trend in this region compared to India. The amount of PAN-observed in the anticyclone over the ASM region depends on the transport pathways of the air mass. During the monsoon season, the air mass in the anticyclone is from polluted regions of Asia. The polluted air $\left(\mathrm{NO}_{\mathrm{x}}\right.$ and VOCs) from these regions transports high amount of PAN into the UTLS where temperatures are colder; hence, it will retain more of PAN (Nowak et al., 2004).

The positive trends in lightning activity during monsoon season (Penki and Kamra, 2013; Yang and Li, 2014) will increase lightning-induced reactive nitrogen $\left(\mathrm{NO}_{\mathrm{x}}\right)$ and nitrogen reservoir species $\left(\mathrm{HNO}_{3}, \mathrm{PAN}\right)$. The lightningproduced PAN is readily carried by convective updrafts to the lower stratosphere, where its lifetime is considerably longer (Labrador et al., 2005). The increase in frequency of deep convective clouds over the tropical land mass (Aumann and Ruzmaikin, 2013) may cause an increase in the frequency of vertical transport. Radar, AVHRR, AIRS and MODIS satellite observations show frequent overshoots deep into the tropical tropopause layer during monsoon season (Devasthale and Fueglistaler, 2010; Hassim et al., 2014). The vertical distribution of the seasonal trend suggests that there is an possitive trend in transport of PAN into the lower stratosphere due to deep monsoon convection. Thus, observed increase in UTLS PAN during the monsoon season is related to positive trends in (1) emissions at the surface, (2) frequency of overshooting convection and (3) production from lightning.

In general, the trends estimated from MIPAS-E and ECHAM5-HAMMOZ PAN are larger over China than India at altitudes below $14 \mathrm{~km}$ and vice versa above $14 \mathrm{~km}$. This may be related with the amount of pollution outflow in the upper troposphere and lower stratosphere from India and China. The pollution from China released primarily below $14 \mathrm{~km}$, and Chinese emissions dominate Indian emissions. The pollution from India has substantial outflow above $14 \mathrm{~km}$ due to convective lifting from the southern slopes of the Himalayas.

\section{Impact of enhanced anthropogenic Asian $\mathrm{NO}_{\mathrm{x}}$ on PAN, $\mathrm{HNO}_{3}$ and $\mathrm{O}_{3}$}

The satellite observations and model simulations indicate that boundary layer pollutants are lofted into the UTLS by monsoon convection (Randel et al., 2010; Fadnavis et al., 2013, 2014). In the UTLS, transport occurs through the monsoon anticyclone and across the tropopause (Fadnavis et al., 2013). The transport of boundary layer Asian $\mathrm{NO}_{\mathrm{x}}$ into the UTLS due to monsoon convection is evident in model simulations (see Fig. S5 in the Supplement). In order to better understand the impact of enhanced anthropogenic Asian $\mathrm{NO}_{\mathrm{x}}$ emissions lifted to UTLS by ASM convection on the distribution of PAN, $\mathrm{HNO}_{3}$ and ozone, we calculate the percentage change of these constituents for the Ind38, Chin73, Ind38Chin38, Ind38Chin73 and Ind73 simulations with re- 

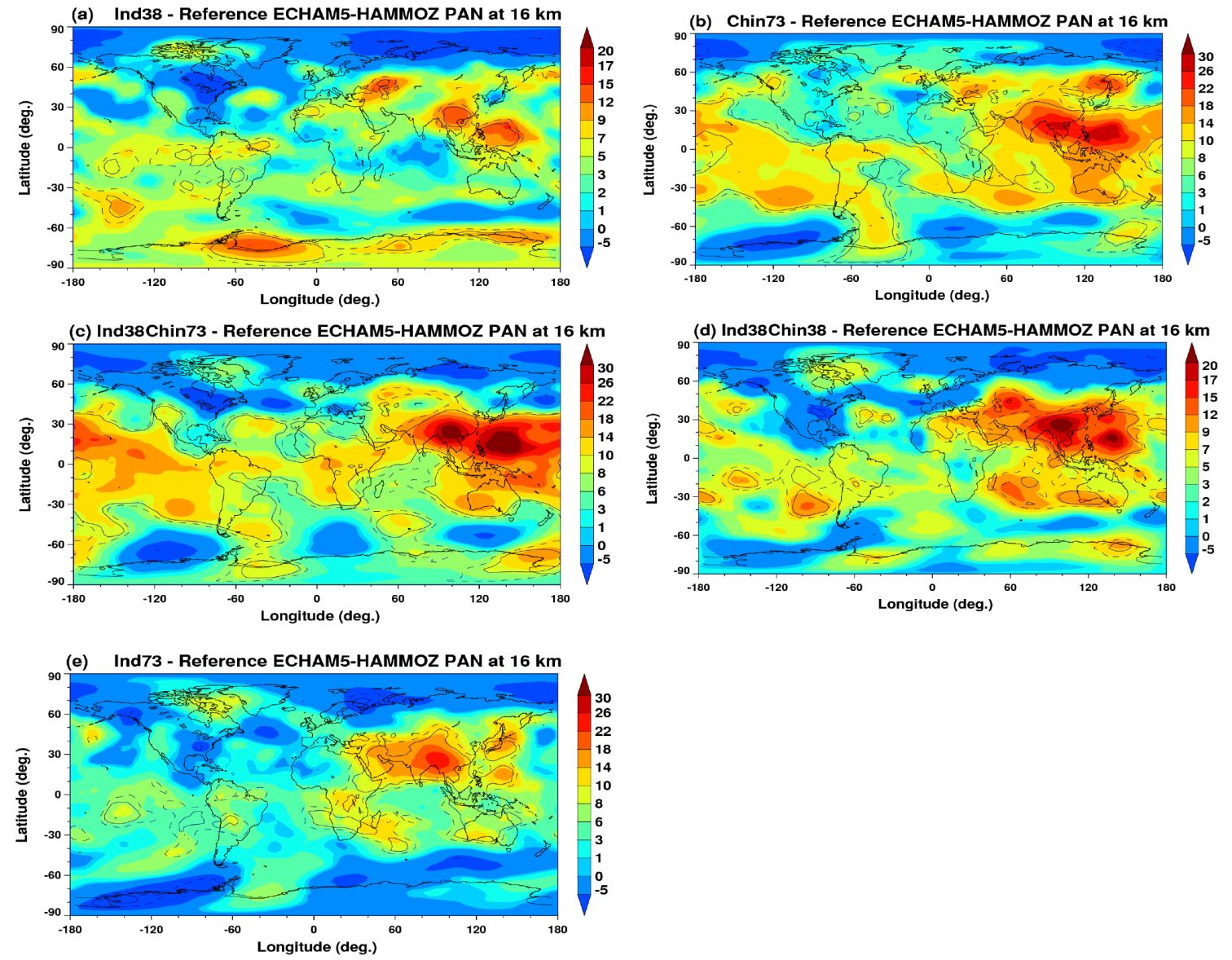

Figure 5. Percentage change in ECHAM5-HAMMOZ PAN at $16 \mathrm{~km}$, as obtained from (a) Ind38, (b) Chin73, (c) Ind38Chin73, (d) Ind38Chin38 and (e) Ind73 simulations. Solid black line indicates the 95\% Student's $t$ test confidence interval while the dashed line indicates $90 \%$ confidence interval.

spect to reference simulations. Although we have analyzed horizontal (latitude-longitude) cross sections at different altitudes within the UTLS $(8-23 \mathrm{~km})$, here we present plots only at $16 \mathrm{~km}$ as a representative of the tropical UTLS layer.

\subsection{Impact on PAN}

Figure 5a-e show the percentage change in PAN at $16 \mathrm{~km}$ for the Ind38, Chin73, Ind38Chin73, Ind38Chin38 and Ind73 simulations. The Ind38 simulation shows an increase in PAN of $\sim 10-18 \%$ with a $95 \%$ significance level over China and the western Pacific Ocean between Indonesia and Japan. Similar high increases also occur over the northern Caspian Sea and the Weddell Sea near Antarctica. The increase in PAN is $\sim 1-6 \%$ over most of the other regions in the midand low latitudes. PAN decreases in polar regions reflecting a change in the diabatic circulation transport with enhanced descent of low PAN air at high latitudes in the stratosphere.

The Chin 73 simulations show an increase in PAN of $\sim 18$ $30 \%$ over China and the western Pacific Ocean between Indonesia and Japan and 10-18\% over India. An increase in
PAN of $\sim 20 \%$ is seen to the north of Japan and $\sim 15 \%$ over the Black Sea, southern Pacific Ocean, southern Indian Ocean and Australia. The increase in PAN over other subpolar regions is $\sim 1-6 \%$. During the monsoon season, the westerly winds in the upper troposphere transport $\mathrm{NO}_{\mathrm{y}}$ from China eastward over the Pacific Ocean. The increased values in the Southern Hemisphere mid-latitudes similar to the maxima in the Northern Hemisphere mid-latitudes indicate a change in the baroclinic eddy storm tracks. Since the PAN in the extratropics shown in Fig. 5 is in the lowermost stratosphere, it is the change in the Rossby waves penetrating from the tropospheric storm tracks that is producing the anomaly structure. This is not a long-range transport feature but a reflection of a change in the circulation.

The Ind38Chin73 simulations (Fig. 5c) show increases of PAN 14-40\% over India, China and the western Pacific and $\sim 10-20 \%$ over the Pacific Ocean $\left(30^{\circ} \mathrm{N}-35^{\circ} \mathrm{S}\right)$. This gives a combined picture of Ind38 and Chin73 simulations, indicating superposing of trends. The outflow over the Pacific Ocean is more pronounced compared to the Chin 73 case, as is to be expected given the Ind38 case shows transport over 

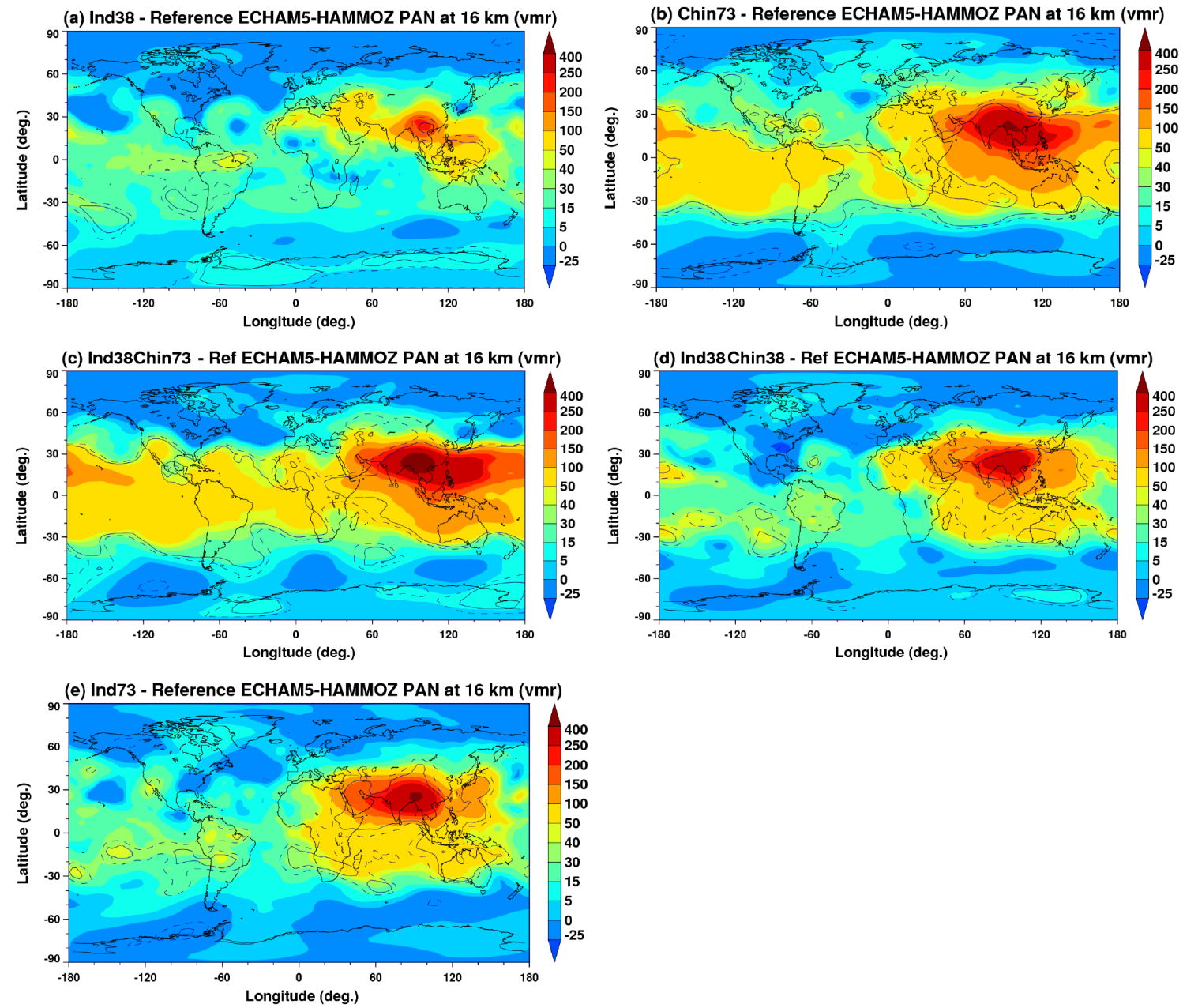

Figure 6. Change in ECHAM5-HAMMOZ PAN at $16 \mathrm{~km}$ in ppt, as obtained from (a) Ind38, (b) Chin73, (c) Ind38Chin73, (d) Ind38Chin38 and (e) Ind73 simulations. Solid black line indicates the $95 \%$ Student's $t$ test confidence interval while the dashed line indicates $90 \%$ confidence interval.

the western Pacific. The percentage increase of PAN in the Ind38Chin38 simulations (Fig. 5d) shows a $\sim 10-25 \%$ increase over India, China and the western Pacific Ocean as in the previous cases. The pattern of PAN increase seen in the Ind38Chin38 case over central Asia and the Black Sea does not persist in the Ind38Chin73 case with non-uniform emissions increases. We attribute this to changes in the dynamics between these simulations that are induced by feedback from ozone and sulfate aerosol produced from $\mathrm{SO}_{2}$ oxidation on the radiation. The baroclinic eddy storm track changes are not the same for the two emissions scenarios. Closer to the emissions source regions the PAN response is more linear.

Figure 6a-d show changes of PAN in ppt. The figures for volume mixing ratio are given instead of percent since they more clearly indicate the transport pathways. There is a common pathway for PAN into the UTLS in response to increases in $\mathrm{NO}_{\mathrm{x}}$ emissions over both India and China in the strong convective uplift over the region of Nepal at the southern flanks of the Himalayas. An ensemble simulation with emissions increased by $73 \%$ instead of $38 \%$, Ind73 (Fig. 5e), produced much higher values of PAN in the anticyclone region but did not produce a significant increase in the outflow over the Pacific Ocean. The increase in PAN for Ind38Chin73 simulation is $5-20 \% \mathrm{yr}^{-1}$ between 10 and $14 \mathrm{~km}$ and $2-4 \% \mathrm{yr}^{-1}$ at the altitudes between 16 and $22 \mathrm{~km}$ over India and China. This is in agreement with observed trends in MIPAS-E PAN $0.5-2 \%$ between 10 and $14 \mathrm{~km}$ and $2-4 \% \mathrm{yr}^{-1}$ between 16 and $22 \mathrm{~km}$. Comparison of Ind73 and Chin73 simulations shows that PAN outflow over the Pacific Ocean is due to primarily to Chinese emissions with increased values over most tropical longitudes in the case of the latter. Doubling $\left(\sim 1.9\right.$ times) the $\mathrm{NO}_{\mathrm{x}}$ emissions over India increases the PAN amounts by $\sim 4-12 \%$ over the ASM region and the western Pacific Ocean in the UTLS. The nonlinear response to increases in $\mathrm{NO}_{\mathrm{x}}$ emissions over India and China is related to transport pathways. Analysis of the PAN distributions at 

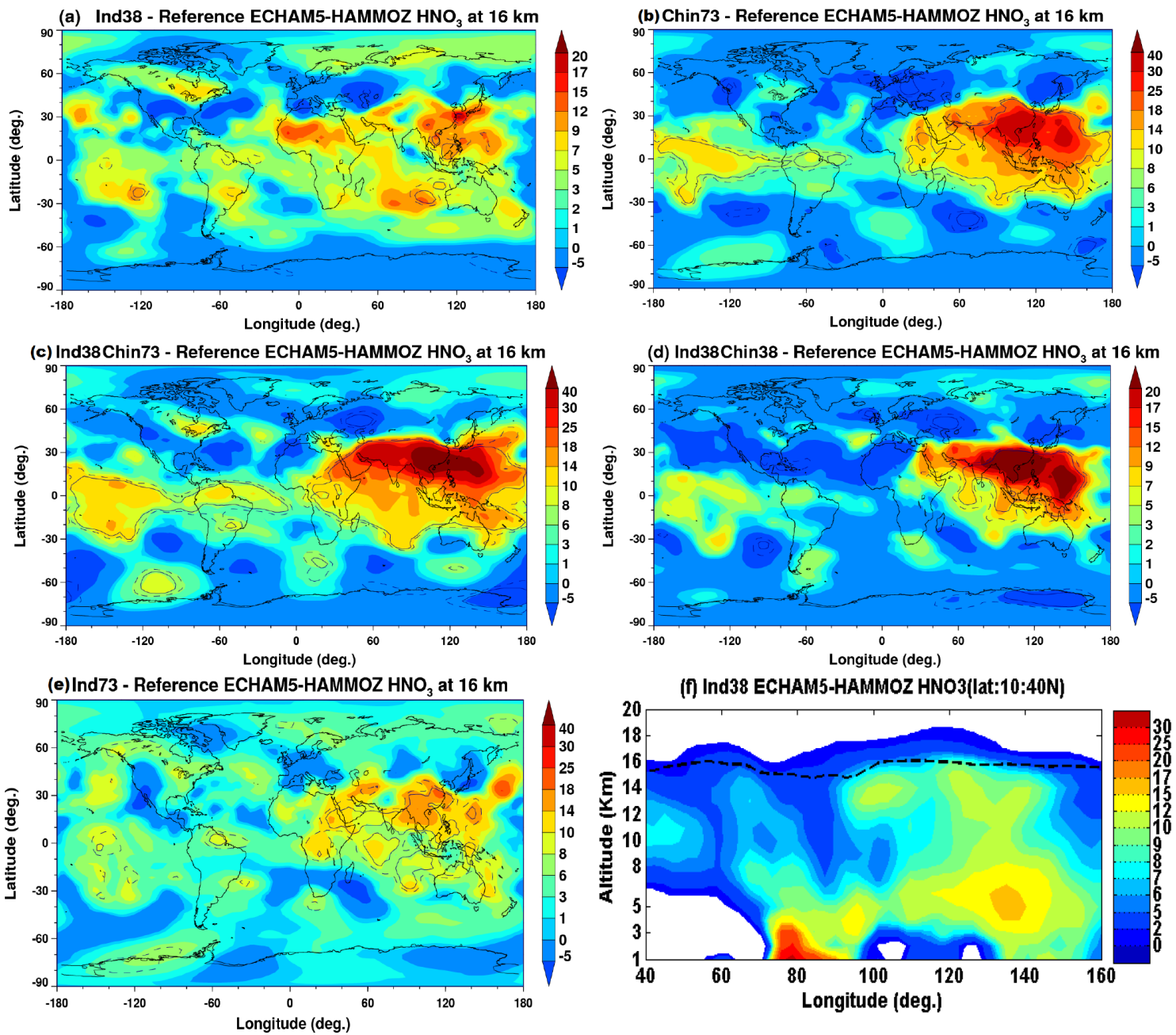

Figure 7. Percentage change in ECHAM5-HAMMOZ $\mathrm{HNO}_{3}$ at $16 \mathrm{~km}$, as obtained from (a) Ind38, (b) Chin73, (c) Ind38Chin73, (d) Ind38Chin38 and (e) Ind73 simulations. Solid black line indicates the $95 \%$ Student's $t$ test confidence interval while the dashed line indicates $90 \%$ confidence interval (f) Longitude-altitude cross section (averaged over $10-40^{\circ} \mathrm{N}$ ) of percentage change in $\mathrm{HNO}_{3}$ for the Ind38 simulation.

different altitudes (not shown) indicates that emissions from India enter the UTLS over the region of Nepal, but emissions from China are transported above $8 \mathrm{~km}$ over eastern China to the north of Vietnam. In the case of Chinese emissions, PAN is transported over the Pacific Ocean at $8 \mathrm{~km}$ and higher altitudes. The Indian emissions are being injected into the ASM anticyclone but a large part of the Chinese emissions enters the UTLS to the east of the anticyclone.

The anticyclone is an effective containment vessel for trace constituents in the UTLS around the tropopause level (Park et al., 2008). Park et al. (2009) found that emissions over India and the Bay of Bengal account for most of the CO in the anticyclone at $100 \mathrm{hPa}$, and emissions over China make a secondary contribution (see their Figs. 9 and 10). Convective detrainment occurs primarily below $150 \mathrm{hPa}$, which is the case over China, and only part of it becomes entrained in the anticyclonic circulation with the rest being transported to the southwest in the Hadley circulation and the northeast over the Pacific Ocean (Jiang et al., 2007; Park et al., 2009).

Another feature apparent in the $16 \mathrm{~km}$ distribution of PAN and the other species covered in this section is that the overall change is positive in the tropics and negative in the extratropics. This indicates an intensification of the Brewer-Dobson circulation since there is no chemical mechanism to explain this pattern for all these species. Changes in the synopticscale circulation are also evident in the positive and negative tracer anomaly structures in the extratropics. At $16 \mathrm{~km}$, this reflects Rossby wave changes induced by shifting of the baroclinic eddy storm tracks in the troposphere associated with the nonlinear dynamical response to heating perturbations in response to chemical changes. 
(a) Ind38 - Reference ECHAM5-HAMMOZ NO at 16 km
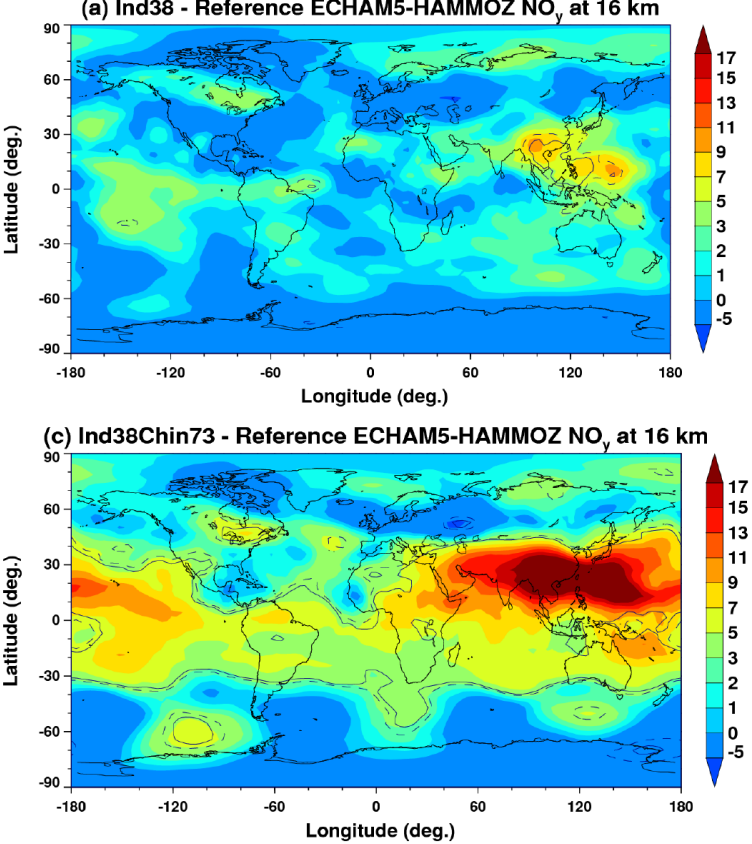

(b) Chin73 - Reference ECHAM5-HAMMOZ NO at 16 km
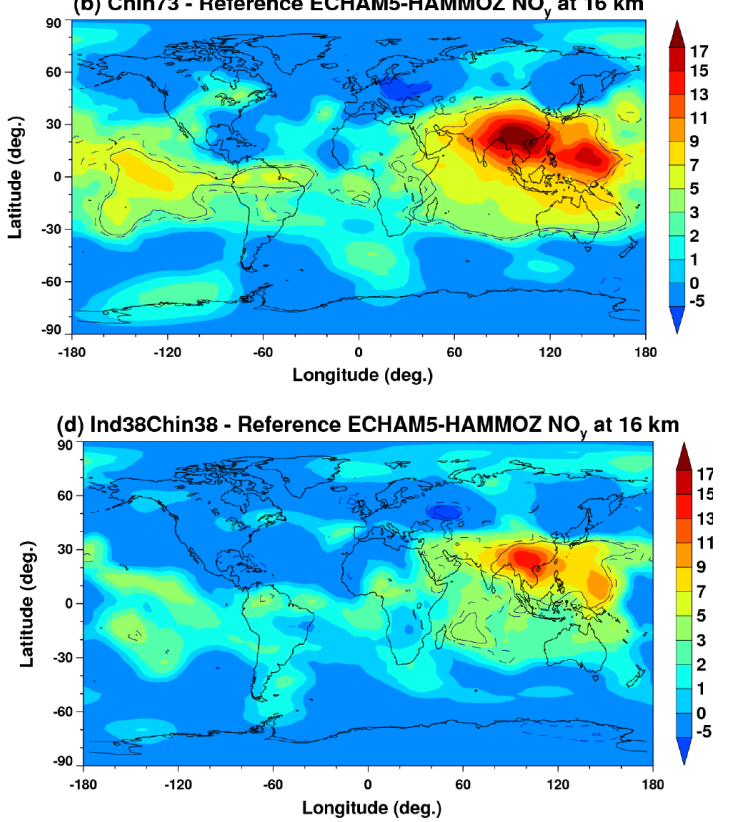

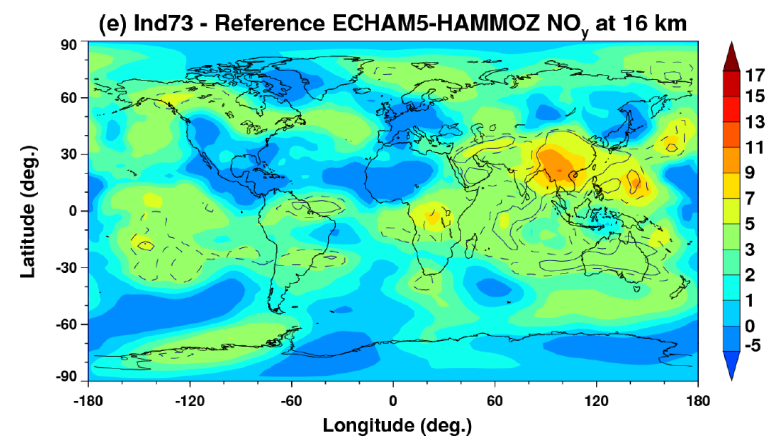

Figure 8. Percentage change in ECHAM5-HAMMOZ NO $\left(\mathrm{NO}+\mathrm{NO}_{2}+\mathrm{NO}_{3}+2 \cdot \mathrm{N}_{2} \mathrm{O}_{5}+\mathrm{HNO}_{3}+\mathrm{HNO} 4+\mathrm{PAN}+\mathrm{MPAN}+\mathrm{ONIT}+\right.$ ONITR + ISOPNO 3 ) at $16 \mathrm{~km}$, as obtained from (a) Ind38, (b) Chin73, (c) Ind38Chin73, (d) Ind38Chin38, and (e) Ind73 simulations. Solid black line indicates the $95 \%$ Student's $t$ test confidence interval while the dashed line indicates $90 \%$ confidence interval.

\subsection{Impact on $\mathrm{HNO}_{3}$}

Changes in the distribution of $\mathrm{HNO}_{3}(\%)$ at $16 \mathrm{~km}$ due to enhanced anthropogenic Asian $\mathrm{NO}_{\mathrm{x}}$ emissions are shown in Fig. 7 a-e. Ind 38 simulations show a $1-5 \%$ increase in $\mathrm{HNO}_{3}$ over most of the regions with a $95 \%$ statistically significant high of $10-14 \%$ over the South China Sea and a high of over 20-25\% over the East China Sea. The Chin73 simulations show an increase in $\mathrm{HNO}_{3}$ in a region between $30^{\circ} \mathrm{S}$ and $30^{\circ} \mathrm{N}$ with few patches over other regions. There is a significant increase in $\mathrm{HNO}_{3} \sim 14-40 \%$ over the monsoon anticyclone and over $30 \%$ over Southeast Asia, China, the South and East China seas and over the western Pacific Ocean south of Japan. There is an increase (95\% confidence level) in $\mathrm{HNO}_{3}$ of $\sim 8-14 \%$ over the tropical Pacific Ocean extending to South America. The Ind38Chin73 and Ind38Chin38 simulations show statistically significant increases of $\mathrm{HNO}_{3}$ in the monsoon anticyclone region. However, when comparing
Indian and Chinese uniform and non-uniform emissions increase cases, it is apparent that a $38 \%$ increase in $\mathrm{NO}_{\mathrm{x}}$ emissions over China is not sufficient to drive a significant $\mathrm{HNO}_{3}$ response over the central and eastern Pacific Ocean. The dynamical response to the $\mathrm{NO}_{\mathrm{x}}$ emissions changes is such that $\mathrm{HNO}_{3}$ is lower in most of the extratropics at $16 \mathrm{~km}$.

\subsection{Impact on $\mathrm{NO}_{\mathrm{y}}$}

In this section we present impact of enhanced $\mathrm{NO}_{\mathrm{x}}$ emissions on $\mathrm{NO}_{\mathrm{y}}$. The $\mathrm{NO}_{\mathrm{y}}$ is computed from

$$
\begin{aligned}
& \mathrm{NO}_{\mathrm{y}}=\mathrm{NO}+\mathrm{NO}_{2}+\mathrm{NO}_{3}+2 \cdot \mathrm{N}_{2} \mathrm{O}_{5}+\mathrm{HNO}_{3}+\mathrm{HNO}_{4} \\
& +\mathrm{PAN}+\mathrm{MPAN}+\mathrm{ONIT}+\mathrm{ONITR}+\mathrm{ISOPNO}_{3} .
\end{aligned}
$$

The impact of enhanced $\mathrm{NO}_{\mathrm{x}}$ emissions over India and China (Fig. 8a-e) leads to changes in $\mathrm{NO}_{\mathrm{y}}$ (in the UTLS) similar to PAN and $\mathrm{HNO}_{3}$ (see Figs. 5 and 7). The increase in $\mathrm{NO}_{\mathrm{x}}$ emissions over the Indian region leads to an increase of high 

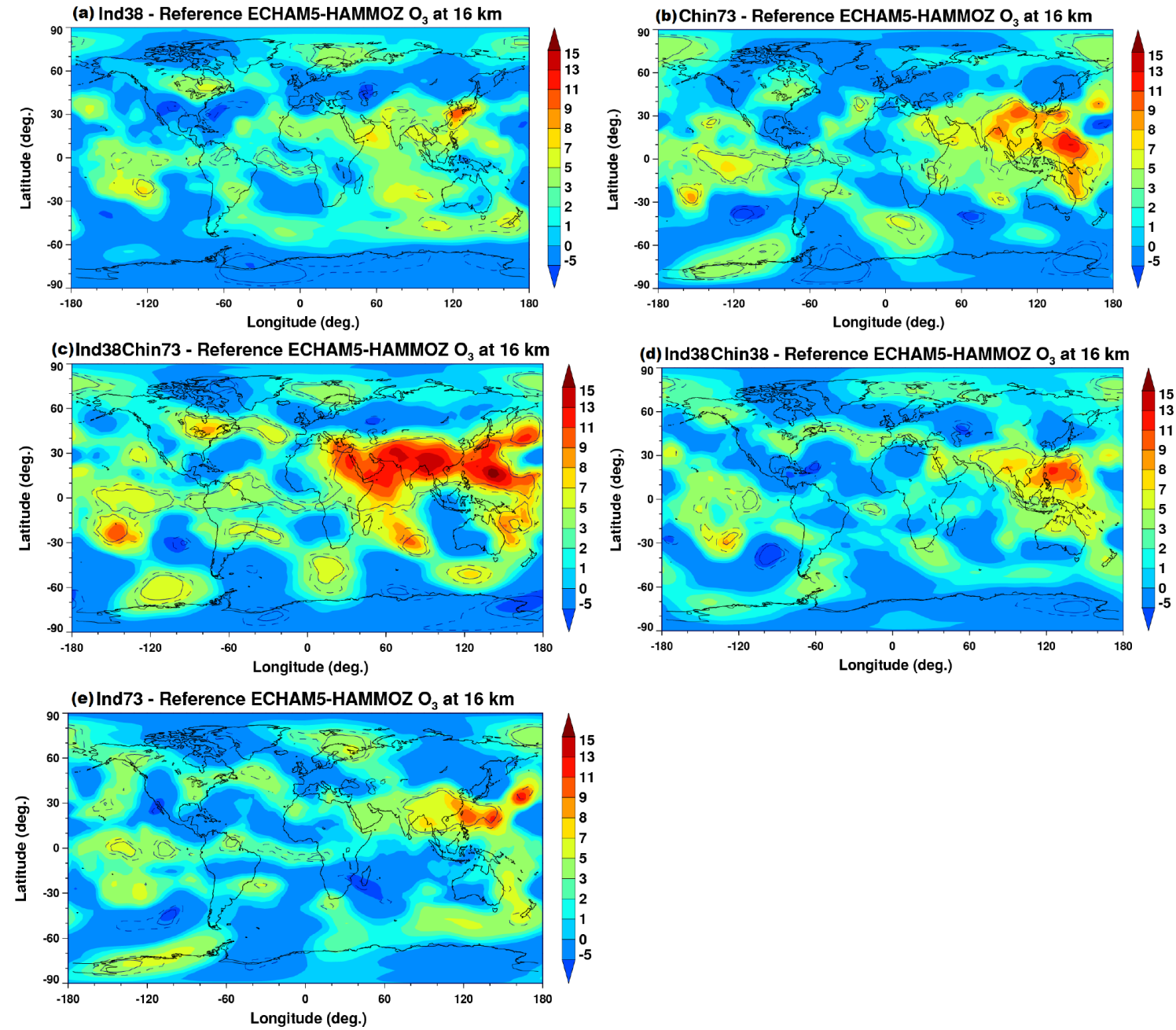

Figure 9. Percentage change in ECHAM5-HAMMOZ ozone at $16 \mathrm{~km}$, as obtained from (a) Ind38, (b) Chin73, (c) Ind38Chin73, (d) Ind38Chin38 and (e) Ind73 simulations. Solid black line indicates the $95 \%$ Student's $t$ test confidence interval while the dashed line indicates $90 \%$ confidence interval.

amounts of $\mathrm{NO}_{\mathrm{y}}$ over China (1-11\%) and the western Pacific Ocean $(2-11 \%)$, while an increase in $\mathrm{NO}_{\mathrm{x}}$ emissions over China increases $\mathrm{NO}_{\mathrm{y}}$ over India $(2-15 \%)$, Southeast Asia $(3-11 \%)$, the South China Sea $(7-15 \%)$, the Indian Ocean (3-15\%) and Pacific Ocean (2-15\%).

Figures 5-8 show that increases in $\mathrm{NO}_{\mathrm{x}}$ emissions over India increase PAN, $\mathrm{HNO}_{3}$ and $\mathrm{NO}_{\mathrm{y}}$ in the UTLS over Southeast Asia and the South China Sea. Concentrations of these species are lower over the Indian region, especially near southern parts of the Himalaya, from where boundary layer Indian pollutants are transported into the monsoon anticyclone (Fadnavis et al., 2013). However, increase in $\mathrm{NO}_{\mathrm{x}}$ emissions over China increases $\mathrm{PAN}, \mathrm{HNO}_{3}$ and $\mathrm{NO}_{\mathrm{y}}$ into the monsoon anticyclone. Part of these emissions is taken up by the westerly winds and is transported over the $\mathrm{Pa}$ cific Ocean. Similar increases in $\mathrm{PAN}, \mathrm{HNO}_{3}$ and $\mathrm{NO}_{\mathrm{y}}$ are also observed for the Ind38Chin38 and Ind38Chin73 simula- tions. The low concentration of $\mathrm{HNO}_{3}, \mathrm{PAN}$ and $\mathrm{NO}_{\mathrm{y}}$ over the convection region of the Himalaya may be due to the removal of $\mathrm{NO}_{\mathrm{x}}$ by wet scavenging. The ozone distribution at $860 \mathrm{hPa}$ (figure not shown) for the Ind38 simulations shows high anomalies over India, which makes its way over the $\mathrm{Pa}$ cific Ocean to North America. The longitudinal transect of $\mathrm{HNO}_{3}$ (see Fig. 7f) indicates that $\mathrm{HNO}_{3}$ is depleted at around $100^{\circ} \mathrm{E}$ and this removal process is less effective going farther to the east, i.e., over China and Southeast Asia. It is possible that the extra $\mathrm{NO}_{\mathrm{x}}$ over India is being locked up as $\mathrm{HNO}_{3}$ and removed by wet scavenging. High amount of water vapor present in the atmosphere during the monsoon season may remove $\mathrm{NO}_{\mathrm{x}}$ by the reactions $\mathrm{NO}_{2}+\mathrm{OH} \rightarrow \mathrm{HNO}_{3}$ and $\mathrm{N}_{2} \mathrm{O}_{5}+2 \mathrm{H}_{2} \mathrm{O} \rightarrow 2 \mathrm{HNO}_{3}$ that suggests $\mathrm{HNO}_{3}$ is more active in the convective zone south of the Himalayas. So the efficiency of $\mathrm{NO}_{\mathrm{x}}$ conversion to $\mathrm{HNO}_{3}$ is larger compared to that over China. A number of previous studies (Holland and 
Lamarque, 1997; Shepon et al., 2007) have reported that wet deposition of $\mathrm{HNO}_{3}$ is the most important pathway of $\mathrm{NO}_{\mathrm{x}}$ removal in the free troposphere. The ECHAM5-HAMMOZ analysis of convective heating and vertical ascent in the troposphere over the region of Nepal is more intense than convective systems over China. This indicates that $\mathrm{HNO}_{3}$ differences are not only due to transport but may reflect differences in wet deposition as well.

\subsection{Impact on ozone}

Changes in ozone at $16 \mathrm{~km}$ due to enhanced Asian anthropogenic $\mathrm{NO}_{\mathrm{x}}$ are shown in Fig. 9a-e. An increase in $\mathrm{NO}_{\mathrm{x}}$ emissions over India (Ind38) increases ozone (3-7\% or 20$60 \mathrm{ppt}$ ) over the Indian Ocean and South China Sea. The Chin73, Ind38Chin38 and Ind38Chin73 simulations show an increase in ozone (3-10\% or 20-100 ppt) over India, the Indian Ocean, Southeast Asia, the South China Sea and the Pacific Ocean, indicating transport by westerly winds. The uniform increase in $\mathrm{NO}_{\mathrm{x}}$ over India and China (Ind73 and Chin73) simulations show greater increases in ozone in the monsoon anticyclone in the case of Chinese emissions compared to emissions from India. This is due to removal of $\mathrm{NO}_{\mathrm{x}}$ by wet scavenging in the region near the Himalayas. In the stratosphere, the impact of enhanced anthropogenic $\mathrm{NO}_{\mathrm{x}}$ emissions is to reduce ozone. ECHAM5-HAMMOZ simulations show a reduction in ozone in the stratosphere $(<70 \mathrm{hPa})$. The highest ozone loss for the Ind38 simulation is $\sim 0.5-2 \%$ in the stratosphere.

\section{Conclusions}

Analysis of PAN estimates from MIPAS satellite for the period 2002-2011 and ECHAM5-HAMMOZ global model simulations shows transport of boundary layer PAN into the monsoon anticyclone due to strong convection. The latitudealtitude and longitude-altitude cross-section maps reveal transport mainly occur from the strong convection regions of the South China Sea $\left(\sim 100-120^{\circ} \mathrm{E}\right)$ and the southern flank of the Himalayas $\left(\sim 80-90^{\circ} \mathrm{E}\right)$. These results are in agreement with previous studies (Fu et al., 2006; Park et al., 2009; Chen et al., 2012; Fadnavis et al., 2013), indicating significant vertical transport by deep convection and diabaticheating-induced upwelling. However, the model simulations reproduce the main features, e.g., a maximum in monsoon anticyclone and vertical transport into the UTLS and the MIPAS-E PAN values are higher than in the model by 3060 ppt. The comparison of MIPAS-E PAN measurements with ACE-FTS indicates that MIPAS-E PAN is higher by $\sim 70 \mathrm{ppt}$ at the altitudes between 9.5 and $17.5 \mathrm{~km}$ (Tereszchuk et al., 2013).

The MIPAS-E PAN observations in the UTLS over India and China show annual trends in PAN varying between $0.4 \pm 1.3$ and $3.2 \pm 0.49$ ppt yr $^{-1}$ over India and $1 \pm 0.25$ and
$3.4 \pm 1.3 \mathrm{ppt} \mathrm{yr}^{-1}$ over China. The seasonal trends are positive, varying between $0.5 \pm 0.8$ and $2.7 \pm 0.47 \mathrm{ppt} \mathrm{yr}^{-1}$ over India and $0.95 \pm 1.2$ and $2.9 \pm 0.45 \mathrm{ppt} \mathrm{yr}^{-1}$ over China. In general, the estimated trends are statistically significant at $2 \sigma$ except in the upper troposphere over India, where positive and negative trends are statistically insignificant. These statistically insignificant trends may be related to convective transport from the southern parts of the Himalaya and removal of $\mathrm{NO}_{\mathrm{x}}$ by wet scavenging. Model simulations for enhanced $\mathrm{NO}_{\mathrm{x}}$ emissions over India also show a nonlinear increase in PAN in the upper troposphere. The estimated seasonal trends are higher than annual trends at altitudes above $14 \mathrm{~km}$ over the Indian, Chinese and ASM regions. This may be due to transport by stronger deep convective activity during the monsoon season as observed in radar, AVHRR, AIRS and MODIS (e.g., Devasthale and Fueglistaler, 2010; Hassim et al., 2014). The observed increasing frequency of overshooting convection over the tropical land mass (Aumann and Ruzmaikin, 2013) indicates an increasing trend in transport across the tropical tropopause in agreement with our results. Quantification of changes in UTLS-PAN due to overshooting convection is beyond the scope of this study. The trends estimated from observations and model simulations are higher over China as compared to India at altitudes below $14 \mathrm{~km}$ and vice versa above $14 \mathrm{~km}$. This may be related with the amount of pollution outflow in the upper troposphere and lower stratosphere from India and China. The pollution from China is released primarily below $14 \mathrm{~km}$ and Chinese emissions dominate Indian emissions. The pollution from India has substantial outflow above $14 \mathrm{~km}$ due to convective lifting from southern slopes of the Himalayas.

The trends estimated from sensitivity simulations for Ind38Chin73 are less than the trends in MIPAS-E PAN as simulations do not account for increases in VOCs. However Ind38Chin73 could reproduce variations similar to MIPASE observations, higher trend values over China (compared to India) in the upper troposphere and vice versa in the lower stratosphere. The sensitivity simulations for an increase in $\mathrm{NO}_{\mathrm{x}}$ emissions over the Indian region lead to an increase of $\mathrm{PAN}, \mathrm{HNO}_{3}$ and ozone over China and the western Pacific Ocean, while an increase in $\mathrm{NO}_{\mathrm{x}}$ emissions over China increases PAN over a larger region covering India, Southeast Asia, the South China Sea, Indian Ocean and Pacific Ocean. A comparison of uniform increases in $\mathrm{NO}_{\mathrm{x}}$ over India and China (Ind73 and Chin73) shows that the effects on PAN, $\mathrm{HNO}_{3}$ and $\mathrm{O}_{3}$ mixing ratios in the anticyclone are more pronounced for Chinese emissions than for Indian emissions. Doubling ( $\sim 1.9$ times) the $\mathrm{NO}_{\mathrm{x}}$ emissions over India shows a nonlinear increase in $\mathrm{PAN}, \mathrm{HNO}_{3}$ and $\mathrm{O}_{3}$ over the ASM and the western Pacific UTLS. The non linear response is related to transport pathways. Emissions over India are injected at the eastern end of the monsoon anticyclone by the deep convection over the southern slopes of the Himalayas. A comparison of the India and China simulations shows an increase in $\mathrm{NO}_{\mathrm{x}}$ over India, resulting in lower concentrations 
of PAN, $\mathrm{HNO}_{3}$ over the Indian region especially near southern parts of the Himalaya, from where boundary layer Indian pollutants are transported into the monsoon anticyclone. The low concentration of PAN and $\mathrm{HNO}_{3}$ over this region is due to removal of $\mathrm{NO}_{\mathrm{x}}$ by wet scavenging. This may be due to a higher efficiency of $\mathrm{NO}_{\mathrm{x}}$ conversion to $\mathrm{HNO}_{3}$ over India compared to China. However, an increase in $\mathrm{NO}_{\mathrm{x}}$ emissions over China increases PAN and $\mathrm{HNO}_{3}$ in the monsoon anticyclone. A part of these emissions is taken up by the westerly winds and is transported over the Pacific Ocean as far as the Atlantic. There is also westward transport by tropical easterlies which may explain part of the signal over the Atlantic Ocean in the tropics and the Southern Hemisphere. Crossequatorial transport into the Southern Hemisphere over the south Indian Ocean occurs as well due to mixing by breaking Rossby waves around the equatorial tropopause and via the meridional overturning, or diabatic, circulation. This indicates that Chinese emissions have a greater impact on the concentrations of these species than Indian emissions.

\section{The Supplement related to this article is available online at doi:10.5194/acp-14-12725-2014-supplement.}

Acknowledgements. The authors thank the staff of the High Power Computing Centre (HPC) in IITM, Pune, India for providing computer resources. S. Fadnavis acknowledges with gratitude B. N. Goswami, Director of IITM, for his encouragement during the course of this research.

Edited by: B. N. Duncan

\section{References}

Anderson, J. G., Wilmouth, D. M., Smith,J. B., and Sayres, D. S.: UV Dosage Levels in Summer: Increased Risk of Ozone Loss from Convectively Injected Water Vapor, Science, 337, 835-839, 2012.

Aumann, H. H. and Ruzmaikin, A.: Frequency of deep convective clouds in the tropical zone from 10 years of AIRS data, Atmos. Chem. Phys., 13, 10795-10806, doi:10.5194/acp-1310795-2013, 2013.

Bhatt, B. C., Koh, T.-Y., Yamamoto, M., and Nakamura, K.: The Diurnal Cycle of Convective Activity over South Asia as Diagnosed from METEOSAT-5 and TRMM Data, Terr. Atmos. Ocean. Sci., 21, 841-854, doi:10.3319/TAO.2010.02.04.01(A), 2010.

Chen, B., Xu, X. D., Yang, S., and Zhao, T. L.: Climatological perspectives of air transport from atmospheric boundary layer to tropopause layer over Asian monsoon regions during boreal summer inferred from Lagrangian approach, Atmos. Chem. Phys., 12, 5827-5839, doi:10.5194/acp-12-5827-2012, 2012.

Choi, K.-C., Woo, J.-H., Kim, H. K., Choi, J., Eum, J.-H. and Baek, B. H.: Modeling of Emissions from Open Biomass Burning in
Asia Using the BlueSky Framework, Asian J. Atmos. Environ. 7-1, 25-37, doi:10.5572/ajae.2013.7.1.025, 2013.

Cooper, O. R., Eckhardt, S., Crawford, J. H., Brown, C. C., Cohen, R. C., Bertram, T. H., Wooldridge, P., Perring, A., Brune, W. H., Ren, X., Brunner, D., and Baughcum, S. L.: Summertime buildup and decay of lightning $\mathrm{NO}_{\mathrm{x}}$ and aged thunderstorm outflow above North America, J. Geophys. Res., 114, D01101, doi:10.1029/2008JD010293, 2009.

Devasthale, A. and Fueglistaler, S.: A climatological perspective of deep convection penetrating the TTL during the Indian summer monsoon from the AVHRR and MODIS instruments, Atmos. Chem. Phys., 10, 4573-4582, doi:10.5194/acp-10-45732010, 2010.

Dodion, J., Fussen, D., Vanhellemont, F., Bingen, C., Mateshvili, N., Gilbert, K., Skelton, R., Turnball, D., McLeod, S. D., Boone, C. D., Walker, K. A., and Bernath P. F.: Aerosols and clouds in the upper troposphere-lower stratosphere region detected by GOMOS and ACE: Intercomparison and analysis of the years 2004 and 2005, Adv. Space Res., 42, 1730-1742, doi:10.1016/j.asr.2007.09.027, 2008.

Emmons, L. K., Hauglustaine, D. A., Muller, J.-F., Carroll, M. A., Brasseur, G. P., Brunner, D., Staehelin, J., Thouret, V., and Marenco A.: Data composites of tropospheric ozone and its precursors from aircraft measurements, J. Geophys. Res., 105, 20497-20538, 2000.

Fadnavis, S., Semeniuk, K., Pozzoli, L., Schultz, M. G., Ghude, S. D., Das, S., and Kakatkar, R.: Transport of aerosols into the UTLS and their impact on the Asian monsoon region as seen in a global model simulation, Atmos. Chem. Phys., 13, 8771-8786, doi:10.5194/acp-13-8771-2013, 2013.

Fadnavis, S., Semeniuk, K., Schultz, M. G., Mahajan, A., Pozzoli, L., Sonbawane, S., and Kiefer, M.: Transport pathways of peroxyacetyl nitrate in the upper troposphere and lower stratosphere from different monsoon systems during the summer monsoon season, Atmos. Chem. Phys. Discuss., 14, 20159-20195, doi:10.5194/acpd-14-20159-2014, 2014.

Fiore, A. M., Horowitz, L. W., Purves, D. W., Levy II, H., Evans, M. J., Wang, Y., Li, Q., and Yantosca, R. M.: Evaluating the contribution of changes in isoprene emissions to surface ozone trends over the eastern United States, J. Geophys. Res., 110, D12303, doi:10.1029/2004JD005485, 2005.

Fischer, E. V., Jacob, D. J., Yantosca, R. M., Sulprizio, M. P., Millet, D. B., Mao, J., Paulot, F., Singh, H. B., Roiger, A.-E., Ries, L., Talbot, R. W., Dzepina, K., and Pandey Deolal, S.: Atmospheric peroxyacetyl nitrate (PAN): a global budget and source attribution, Atmos. Chem. Phys. Discuss., 13, 26841-26891, 2013, http://www.atmos-chem-phys-discuss.net/13/26841/2013/.

Fischer, H. and Oelhaf, H.: Remote sensing of vertical profiles of atmospheric trace constituents with MIPAS limb-emission spectrometers, Appl. Optics, 35, 2787-2796, 1996.

Fischer, H., Birk, M., Blom, C., Carli, B., Carlotti, M., von Clarmann, T., Delbouille, L., Dudhia, A., Ehhalt, D., Endemann, M., Flaud, J. M., Gessner, R., Kleinert, A., Koopman, R., Langen, J., Lopez-Puertas, M., Mosner, P., Nett, H., Oelhaf, H., Perron, G., Remedios, J., Ridolfi, M., Stiller, G., and Zander, R.: MIPAS: an instrumenti, Atmos. Chem. Phys., 8, 2151-2188, doi:10.5194/acp-8-2151-2008, 2008.

Fu, R., Hu, Y., Wright, J. S., Jiang, J. H., Dickinson, R. E., Chen, M., Filipiak, M., Read, W. G., Waters, J. W., and 
Wu, D. L.: Short circuit of water vapour and polluted air to the global stratosphere by convective transport over the Tibetan Plateau, Proc. Natl. Acad. Sci. USA, 103, 5664-5669, doi:10.1073/pnas.0601584103, 2006.

Ganzeveld, L. and Lelieveld, J.: Dry deposition parameterization in a chemistry general circulation model and its influence on the distribution of reactive trace gases, J. Geophys. Res.,100, 20999 21012, doi:10.1029/95JD02266, 1995.

Gettelman, A., Kinnison, D. E., Dunkerton, T. J., and Brasseur, G. P.: The impact of monsoon circulations on the upper troposphere and lower stratosphere, J. Geophys. Res., 109, D22101, doi:10.1029/2004JD004878, 2004.

Ghude, S. D., Kulkarni, S. H., Jena, C., Pfister, G. G., Beig, G., Fadnavis, S., and van der A R. J.: Application of satellite observations for identifying regions of dominant sources of nitrogen oxides over the Indian Subcontinent, J. Geophys. Res., 118, 115, doi:10.1029/2012JD017811, 2013.

Glatthor, N., Von Clarmann T., Fischer, H., Funke, B., Grabowski, U., Höpfner, M., Kellmann, S., Kiefer, M., Linden, A., Milz, M., Steck, T., and Stiller, G. P.: Global peroxyacetyl nitrate (PAN) retrieval in the upper troposphere from limb emission spectra of the Michelson Interferometer for Passive Atmospheric Sounding (MIPAS), Atmos. Chem. Phys., 7, 2775-2787, doi:10.5194/acp7-2775-2007, 2007.

Hassim, M. E. E., Lane, T. P., and May, P. T.: Ground-based observations of overshooting convection during the Tropical Warm Pool-International Cloud Experiment, J. Geophys. Res. Atmos.,119, 880-905, doi:10.1002/2013JD020673, 2014.

Hilboll, A., Richter, A., and Burrows, J. P.: Long-term changes of tropospheric $\mathrm{NO}_{2}$ over megacities derived from multiple satellite instruments, Atmos. Chem. Phys., 13, 4145-4169, doi:10.5194/acp-13-4145-2013, 2013.

Holland, E. A., and Lamarque J. F.: Modeling bio-atmospheric coupling of the nitrogen cycle through $\mathrm{NO}_{\mathrm{x}}$ emissions and NOy deposition, Nutr. Cycl. Agroecosyst., 48, 7-24, 1997.

Horowitz, L. W., Walters, S., Mauzerall, D. L., Emmons, L. K., Rasch, P. J., Granier, C., Tie, X., Lamarque, J., Schultz, M. G.,Tyndall, G. S., Orlando, J. J., and Brasseur, G. P.: A global simulation of tropospheric ozone and related tracers, Description and evaluation of MOZART, version 2, J. Geophys. Res., 108, 4784, doi:10.1029/2002JD002853, 2003.

Jiang, J. H., Livesey, N. J., Su, H., Neary, L., McConnell, J. C., and Richards, N. A. D.: Connect, ing surface emissions, convective uplifting, and long-range transport of carbon monoxide in 20 the upper troposphere: New observations from the Aura Microwave Limb Sounder, Geophys. Res. Lett., 34, L18812, doi:10.1029/2007GL030638, 2007.

Keim, C., Liu, G. Y., Blom, C. E., Fischer, H., Gulde, T., Höpfner, M., Piesch, C., Ravegnani, F., Roiger, A., Schlager, H., and Sitnikov, N.: Vertical profile of peroxyacetyl nitrate (PAN) from MIPAS-STR measurements over Brazil in February 2005 and its contribution to tropical UT NOy partitioning, Atmos. Chem. Phys., 8, 4891-4902, doi:10.5194/acp-8-4891-2008, 2008.

Labrador, L. J., von Kuhlmann, R., and Lawrence, M. G:: The effects of lightning-produced $\mathrm{NO}_{\mathrm{x}}$ and its vertical distribution on atmospheric chemistry: sensitivity simulations with MATCHMPIC, Atmos. Chem. Phys., 5, 1815-1834, doi:10.5194/acp-51815-2005, 2005.
Li, Q., Jiang, J. H., Wu, D. L., Read, W. G., Livesey, N. J.,. Waters, J. W:, Zhang, Y., Wang, B., Filipiak, M. J., Davis, C. P., Turquety, S., Wu, S., Park, R. J., Yantosca, R. M., and Jacob, D. J.: Convective outflow of South Asian pollution: A global CTM simulation compared with EOS MLS observations, Geophys. Res. Lett., 32, L14826, doi:10.1029/2005GL022762, 2005.

Nesbitt, S. W., Zhang, R., and Orville, R. E.: Seasonal and global NOxproduction by lightning estimated from the optical transient detector (OTD), Tellus B, 52, 1206-1215, 2000.

Nowak, J., Parris, D. D., Neuman, J. A., Holloway, J. S., Cooper. O. R., Ryerson, T. B., Nicks, D. K., Flocke, F., Roberts, J. M., Atlas, E., de Gouw, J. A., Donnelly, S., Dunlea, E., Hubler, G., Huey, L. G., Schauffler, S., Tanner, D. J., Warneke, C., and Fehsenfeld, F. C. S.: Gas-phase chemical characteristics of Asian emission plumes observed during ITCT 2K2 over the eastern North Pacific Ocean, J. Geophys. Res., 109, D23S19, doi:10.1029/2003JD004488, 2004.

Ohara, T., Akimoto, H., Kurokawa, J., Horii, N., Yamaji, K., Yan, X., and Hayasaka, T.: An Asian emission inventory of anthropogenic emission sources for the period 1980-2020, Atmos. Chem. Phys., 7, 4419-4444, doi:10.5194/acp-7-4419-2007, 2007.

Park, M., Randel, W. J., Kinnison, D. E., Garcia, R. R., and Choi, W.: Seasonal variation of methane, water vapour, and nitrogen oxides near the tropopause: Satellite observations and model simulations, J. Geophys. Res., 109, D03302, doi:10.1029/2003JD003706, 2004.

Park, M., Randel, W. J., Getteleman, A., Massie, S. T., and Jiang, J. H.: Transport above the Asian summer monsoon anticyclone inferred from Aura Microwave Limb Sounder tracers, J. Geophys Res., 112, D16309, doi:10.1029/2006JD008294, 2007.

Park M., Randel, W. J., Emmons, L. K., Bernath, P. F., Walker, K. A. and Boone, C. D.: Chemical isolation in the Asian monsoon anticyclone observed in Atmospheric Chemistry Experiment (ACEFTS) data, Atmos. Chem. Phys., 8, 757-764, doi:10.5194/acp-8757-2008, 2008.

Park, M., Randel, W. J., Emmons, L. K., and Livesey, N. J.: Transport pathways of carbon monoxide in the Asian summer monsoon diagnosed from Model of Ozone and Related Tracers (MOZART), J. Geophys. Res., 114, D08303, doi:10.1029/2008JD010621, 2009.

Penki, R. K. and Kamra, A. K.: Lightning distribution with respect to the monsoon trough position during the Indian summer monsoon season, J. Geophy. Res., 118, 4780-4787, doi:10.1002/jgrd.50382, 2013.

Pozzoli, L., Bey, I., Rast, J. S., Schultz, M. G., Stier, P., and Feichter, J.: Trace gas and aerosol interactions in the fully coupled model of aerosol-chemistry-climate ECHAM5- HAMMOZ: 1. Model description and insights from the spring 2001 TRACE-P experiment, J. Geophys. Res., 113, D07308, doi:10.1029/2007JD009007, 2008a.

Pozzoli, L., Bey, I., Rast, J. S., Schultz, M. G., Stier, P., and Feichter, J.: Trace gas and aerosol interactions in the fully coupled model of aerosol-chemistry-climate ECHAM5- HAMMOZ: 2. Impact of heterogeneous chemistry on the global aerosol distributions, J. Geophys. Res., 113, D07309, doi:10.1029/2007JD009008, 2008b.

Pozzoli, L., Janssens-Maenhout, G., Diehl, T., Bey, I., Schultz, M. G., Feichter, J., Vignati, E., and Dentener, F.: Re-analysis of tro- 
pospheric sulfate aerosol and ozone for the period 1980-2005 using the aerosol-chemistry-climate model ECHAM5-HAMMOZ, Atmos. Chem. Phys., 11, 9563-9594, doi:10.5194/acp-11-95632011, 2011.

Ranalkar M. R. and Chaudhari, H. S.: Seasonal variation of lightning activity over the Indian subcontinent, Meteorol. Atmos. Phys., 104, 125-134, 2009.

Randel, W. J. and Park, M.: Deep convective influence on the Asian summer monsoon anticyclone and associated tracer variability observed with Atmospheric Infrared Sounder (AIRS), J. Geophys. Res., 111, D12314, doi:10.1029/2005JD006490, 2006.

Randel, W. J. and Jensen, E. J.: Physical processes in the tropical tropopause layer and their roles in a changing climate, Nature Geosci., 6, 169-176, doi:10.1038/ngeo1733, 2013.

Randel, W. J., Park, M., Emmons, L., Kinnison, D., Bernath, P., Walker, K. A., Boone, C., and Pumphrey, H.: Asian monsoon transport of pollution to the stratosphere, Science. 328, 611-613, 2010.

Ravishankara, A. R.: Water Vapor in the Lower Stratosphere, Science, 337, 809-810, doi:10.1126/science.1227004, 2012.

Ridley, B. A., Madronich, S., Chatfield, R. B., Walega, J. G., Shetter, R. E., Carroll, M. A., and Montzka, D. D: Measurements and model simulations of the photostationary state during the Mauna Loa Observatory Photochemistry Experiment: Implications for radical concentrations and ozone production and loss rates, J. Geophys. Res., 97, 10375-10388, doi:10.1029/91JD02287, 1992.

Roeckner, E., Bauml, G., Bonaventura, L., Brokopf, R., Esch, M., Giorgetta, M., Hagemann, S., Kirchner, I., Kornblueh, L., Manzini, E., Rhodin, A., Schlese, U., Schulzweida, U., and Tompkins, A.: The atmospehric general circulation model ECHAM5: Part 1, Tech. Rep. 349, Max Planck Institute for Meteorology, Hamburg, 2003.

Sander, S. P., Fried, R. R., Barker, J. R., Golden, D. M., Kurylo, M. J.,Wine, P. H., J. Abbatt, P. D., 25 Burkholder, J. B., Kolb, C. E., Moortgat, G. K., Huie, R. E., and Orkin, V. L.: Chemical kinetics and photochemical data for use in atmospheric studies, evaluation number 14, JPL Publ. 02-25, Jet Propul. Lab., Calif. Inst. of Technol., Pasadena, available at: http://jpldataeval.jpl.nasa.gov/ pdf/JPL_02-25_rev02.pdf, 2003.

Sander, S. P., Finlayson-Pitts, B. J., Friedl, R. R., Golden, D. M., Huie, R. E., Keller-Rudek, H., 30 Kolb, C. E., Kurylo, M. J., Molina, M. J., Moortgat, G. K., Orkin, V. L., Ravishankara, A. R., and Wine, P. H.: Chemical Kinetics and Photochemical Data for Use in Atmospheric Studies, Evaluation Number 15, JPL Publication 06-2, Jet Propulsion Laboratory, Pasadena, available at: http://jpldataeval.jpl.nasa.gov (last access: July 2006), 2006.

Schneider, P. and van der A. R. J.: A global single-sensor analysis of 2002-2011 tropospheric nitrogen dioxide trends observed from space, J, Geophy. Res., 117, D16309, doi:10.1029/2012JD017571, 2012.

Shepon, A., Gildor, H., Labrador, L. J., Butler, T., Ganzeveld, L. N., and Lawrence, M. G.: Global reactive nitrogen deposition from lightning $\mathrm{NO}_{\mathrm{x}}$, J. Geophys. Res., 112, D06304, doi:10.1029/2006JD007458, 2007.

Singh, H. B., Viezee, W., Chen, Y., Thakur, A. N., Kondo, Y. and Talbot, R. W.,Gregory, G. L., Sachse, G. W., Blake, D. R., Bradshaw, J. D., Wang, Y., and Jacob, D. J.: Latitudinal distribution of reactive nitrogen in the free troposphere over the Pacific Ocean in late winter/early spring, J. Geophys. Res., 103, 28237-28246, doi:10.1029/98JD01891, 1998.

Sinha, V., Kumar, V., and Sarkar, C.: Chemical composition of premonsoon air in the Indo-Gangetic Plain measured using a new air quality facility and PTR-MS: high surface ozone and strong influence of biomass burning, Atmos. Chem. Phys., 14, 59215941, doi:10.5194/acp-14-5921-2014, 2014.

Stier, P., Feichter, J., Kinne, S., Kloster, S., Vignati, E., Wilson, J., Ganzeveld, L., Tegen, I., Werner, M., Balkanski, Y., Schulz, M., Boucher, O., Minikin, A., and Petzold, A.: The aerosol-climate model ECHAM5-HAM, Atmos. Chem. Phys., 5, 1125-1156, doi:10.5194/acp-5-1125-2005, 2005.

Tereszchuk, K. A., Moore, D. P., Harrison, J. J., Boone, C. D., Park, M., Remedios, J. J., Randel, W. J., and Bernath, P. F.: Observations of peroxyacetyl nitrate (PAN) in the upper troposphere by the Atmospheric Chemistry Experiment Fourier Transform Spectrometer (ACE-FTS), Atmos. Chem. Phys., 13, 5601-5613, doi:10.5194/acp-13-5601-2013, 2013.

Tie, X., Zhang, R., Brasseur, G., and Lei, W.: Global NO $\mathrm{X}_{\mathrm{x}}$ Production by Lightning, J. Atmos. Chem., 43, 61-74, 2002.

Tie, X. X., Zhang, R., Brasseur, G., Emmons, L., and Lei, W.: Effects of lightning on reactive nitrogen and nitrogen reservoir species in the troposphere, J. Geophys. Res.-Atmos., 106, 31673178, doi:10.1029/2000JD900565, 2001.

Vernier, J. P., Thomason, L. W., and Kar, J.: CALIPSO detection of an Asian tropopause aerosol layer, Geophys. Res. Lett., 38, L07804, doi:10.1029/2010GL046614, 2011.

non Clarmann, T., Höpfner, M., Kellmann, S., Linden, A., Chauhan, S., Funke, B., Grabowski, U., Glatthor, N., Kiefer, M., Schieferdecker, T., Stiller, G. P., and Versick, S.: Retrieval of temperature, $\mathrm{H}_{2} \mathrm{O}, \mathrm{O}_{3}, \mathrm{HNO}_{3}, \mathrm{CH}_{4}, \mathrm{~N}_{2} \mathrm{O}, \mathrm{ClONO}_{2}$ and $\mathrm{ClO}$ from MIPAS reduced resolution nominal mode limb emission measurements, Atmos. Meas. Tech., 2, 159-175, doi:10.5194/amt-2-2159-2009, 2009.

von Clarmann, T., Stiller, G., Grabowski, U., Eckert, E., and Orphal, J.: Technical Note: Trend estimation from irregularly sampled, correlated data, Atmos. Chem. Phys., 10, 6737-6747, doi:10.5194/acp-10-6737-2010, 2010.

Walker, T. W., Martin, R. V., Donkelaar, A. van, Leaitch, W. R., MacDonald, A. M., Anlauf, K. G., Cohen, R. C., Bertram, T. H., Huey, L. G., Avery, M. A., Weinheimer, A. J., Flocke, F. M., Tarasick, D. W., Thompson, A. M., Streets, D. G., and Liu, X.: TransPacific transport of reactive nitrogen and ozone to Canada during spring, Atmos. Chem. Phys., 10, 8353-8372, doi:10.5194/acp10-8353-2010, 2010.

Wiegele, A., Glatthor, N., Hopfner, M., Grabowski, U., Kellmann, S., Linden, A., Stiller, G., and von Clarmann, T.: Global distributions of $\mathrm{C}_{2} \mathrm{H}_{6}, \mathrm{C}_{2} \mathrm{H}_{2}, \mathrm{HCN}$, and PAN retrieved from MIPAS reduced spectral resolution measurements, Atmos. Meas. Tech., 5, 723-734, doi:10.5194/amt-5-723-2012, 2012.

Wu, Z., Wang, X., Turnipseed, A. A., Chen, F, Zhang, L., Guenther, A. B., Karl, T., and Huey, L. G.: 25 Niyogi, D., Xia, B., and Alapaty, K.: Evaluation and improvements of two community models in simulating dry deposition velocities for peroxyacetyl nitrate (PAN) over a coniferous forest, J. Geophys. Res., 117, D04310, doi:10.1029/2011JD016751, 2012.

Xiong, X., Houweling, S., Wei, J., Maddy, E., Sun, F., and Barnet, C.: Methane plume over South Asia during the monsoon season: 
Satellite observation and model simulation, Atmos. Chem. Phys., 9, 783-794, doi:10.5194/acp-9-783-2009, 2009.

Yang, X. and Z. Li, Z.: Increases in thunderstorm activity and relationships with air pollution in southeast China, J. Geophys. Res. Atmos., 119, 1835-1844, doi:10.1002/2013JD021224, 2014.

Yamaji, K., Ohara, T., Uno, I., Tanimoto, H., Kurokawa, J., and Akimoto, H.: Analysis of the seasonal variation of ozone in the boundary layer in East Asia using the Community Multiscale Air Quality model: what controls surface ozone levels over Japan?, Atmos. Environ., 40, 1856-1868, 2006.
Zhao, C., Wang, Y., Choi, Y., and Zeng, T.: Summertime impact of convective transport and lightning $\mathrm{NO}_{\mathrm{x}}$ production over North America: modeling dependence on meteorological simulations, Atmos. Chem. Phys., 9, 4315-4327, doi:10.5194/acp-9-43152009, 2009. 